\title{
Fossil horses from the Late Pleistocene of Tapalqué Creek (Buenos Aires Province, Argentina)
}

\author{
José L. Prado, Ricardo Bonini, Cristian Favier-Dubois, Gustavo N. Gómez, Pamela Steffan, and \\ María T. Alberdi
}

With 10 figures and 4 tables

\begin{abstract}
A comparative study was made with the known record of equids species in South America, identifying the remains as Equus neogeus, Hippidion devillei, and Hippidion principale. These data increase the record of Equidae in South America and provide new evidence about the chronological and geographical distribution. The sedimentary deposits of the Lujan Formation outcropping at Tapalqué creek ( 4 to $120 \mathrm{ky}$ ) were accumulated through fluvial processes. This Formation comprises a rich vertebrate fauna corresponding to the Lujanian South American Land Mammal Age, which includes numerous and diverse vertebrate remains. The taphonomic analysis indicates that the faunistic assemblage was formed and was subject to diagenetic processes without distinction of its action in the fossiliferous levels, that can be recognized as fluvial deposits.
\end{abstract}

Key words: Equidae, paleoecology, late Pleistocene, taphonomy, Argentina.

\section{Introduction}

The Mammal faunas from the Pleistocene of Argentine Pampas are among the richest and most diverse of South America (PASCUAL etal. 1996). Particularly, the Equidae (Perissodactyla), an immigrant from the North America group, are a major component of many local faunas (e.g., Alberdi etal. 1989; Prado etal. 1987; BARGo etal. 1986; Alberdi etal. 2006; Prado \& Alberdi 2008; Prado et al. 2012). Equidae is a large family that actually includes horses, wild asses, and zebras. The oldest known fossils assigned to Equidae date from the early Eocene of North America, ca. 55 million years ago. The family became relatively diverse during the Miocene, where there is evidence of great adaptive radiation (CANTALAPIEDRA etal. 2017).

The first fossil horses in South America were discovered by DARwIN in Argentina (Owen 1840). Since this publication, notes and articles proliferated, which in most cases do not reflect the global diversity of this group. The several papers of Equidae in South America (Alberdi 1987; Prado etal. 1987; Alberdi etal. 1989; Alberdi \& Prado 1993; Prado \& Alberdi 1994; Prado \& Alberdi 1996; Prado etal. 1998; Prado et al. 2000; Alberdi et al. 2001a; Alberdi et al. 2001b; Alberdi etal. 2003; Alberdi \& Prado 2004; Prado etal. 2005; Prado \& Alberdi 2012; Prado etal. 2013a; Prado etal. 2013b; García etal. 2018; PrADO et al. 2018; among others) distinguish two genera: Equus and Hippidion. Each genus has a specific dental morphology, with a clear intraspecific variability. Hippidion has a more primitive morphology than Equus, and its body structure is more robust (PRADO 1984; Alberdi etal. 1986; Alberdi 1987; Alberdi etal. 1987; Prado \& Alberdi 1994; Prado \& AlBerdi 2014; Prado \& Alberdi 2016; Der SarkisSian et al. 2015; among others). 
The genus Equus first appeared during the Pliocene and was once widespread in grassland and desert habitats through North America, Asia, Africa, and Europe (MACFADDEN 1992). The current distribution is over open habitats of eastern and southern Africa and regions of Asia. The earliest appearance of Equus in South America record corresponds to the middle Pleistocene of Tarija (Bolivia), dated by MACFADDEN etal. (1983) and MAcFADDEN (2013) around 0.99 to $0.76 \mathrm{Ma}$. Many articles have been published to arrange knowledge of the Equus species in South America (Machado et al. 2017). Prado \& Alberdi (2017) reviewed this group and recognized three valid species: Equus andium, Equus insulatus, and Equus neogeus.

The Hippidion genus was defined by Owen (1869) based on a molar from Lagoa Santa (Brazil) and appeared in the publication by LUND (1846). ALBERDI \& Prado (1993) and Prado \& Alberdi (1996) recognized this genus as endemic from South America, where it is recorded from the Pliocene to the late Pleistocene mainly in Argentina, Bolivia, Brazil, Chile, Peru, and Uruguay. Alberdi \& Prado (1993) reviewed this group and recognized three species: Hippidion principale, Hippidion devillei, and Hippidion saldiasi.

The new remains of horse analyzed here come from two fossiliferous localities called Salto de Piedra $\left(36^{\circ} 56^{\prime} 54.6^{\prime \prime} \mathrm{S}\right.$; $\left.60^{\circ} 22^{\prime} 19.9^{\prime \prime} \mathrm{W}\right)$ and Avellaneda profiles, along the Tapalqué creek $\left(36^{\circ} 54^{\prime} 05^{\prime \prime} \mathrm{S}\right.$, $60^{\circ} 20^{\prime} 36^{\prime \prime} \mathrm{W}$ ) near the city of Olavarría, in the Buenos Aires Province. These specimens constitute a new record of horses in South America that completes the description of these species. The aim of this paper is to present a detailed description of this material, its precise taxonomic status, taphonomic context, and stratigraphic location.

\section{Physiography, climate, and environmental settings}

Traditionally, the terms Pampas (from Quechua pampa, meaning plain) or Pampean Region were assigned to the plains encompassing central-eastern Argentina. These vast land plains constitute a natural region (about $750,000 \mathrm{~km}^{2}$ ) and are interrupted by the low hills of the Ventana and Tandil system. The region has a flat to gently undulating landscape, characterized by a deep mantle of loess and loessic silts. The Pampas grasslands include the dry steppes of the moderate continental climate (Dry Pampa) to the east, and the humid temperate prairies (Humid Pampa) to the west (MANCINI etal.
2005). This climatic pattern reflects the dominant effects of the ocean in the southern half of South America (IRIONDO \& GARCÍA 1993).

The Pampa Area is considered to have constituted an ecotone (RINGUELET 1961) between two major biogeographic areas; the Brazilian, and Patagonian subregions. Past faunal associations included shifting mixtures of taxa from both subregions at different times during the late Pleistocene and Holocene. During the cold-dry climatic phase, there was a reduction of the subregions which was occupied by subtropical and tropical faunas, resulting in the expansion and interconnection of open environment faunas. Later, when the open areas retreated during the interglacial periods of the warm-wet climatic phase, the rainforest expanded (TonNI etal. 1992). The arid and semiarid conditions are related to a general decline of mean annual temperatures.

Today, the winds from the South Pacific Anticyclone lose their humidity on the western side of the Andes, and are cold and dry on arriving at the Pampas from the SW and the S, whereas the winds of the South Atlantic Anticyclone are warmer and more humid and arrive in the Pampas from the NE. Tonello \& PRIETO $(2008,2010)$ inferred that the arid conditions during the Late Pleistocene in Pampas Region (ca.16.000 to $12.000 \mathrm{yrs}$ BP) were associated with more continental conditions due to the expansion of the land-mass as a result of a lower sea level in the Atlantic coast. Based on sedimentological (MuHS \& ZÁrATE 2001), palynological (Tonello \& Prieto 2010; QuatTrocchio etal. 2008), isotopic (Bonadonna etal. 1999) and faunal evidence (TONNI et al. 1999; PrADO \& AlBERDI 1999; Tonni et al. 2003), the climate for the Late Pleistocene in the southern Pampas is characterized by a dry climate with ca. $100 \mathrm{~mm}$ lower precipitation levels than at present. This is likely related to the influence of maritime polar air masses, triggered by the northward displacement of the polar front, and the intensification of the westerlies from ice cover in Antarctica and the extent of sea ice, as suggested by Heusser (1989) for high latitudes (QUATTROCCHIO \& BORROMEI 1998).

\section{Stratigraphic and chronological context}

\subsection{Regional framework}

FidAlgo etal. (1973, 1975, 1991) reviewed the stratigraphic nomenclature of the Quaternary of the Pampean Region. Geomorphological evidence en- 
ables two stratigraphic units to be distinguished for the Late Pleistocene and Holocene deposits: the Lujan and the La Postrera formations. The former is of fluvial-lacustrine origin, and the latter is of eolian origin. The wind deposits of La Postrera Formation that cover the entire Pampean Region include loess, very fine stratified sands (ZÁrATE \& BLASI 1993). The sedimentological analysis of wind material (BIDART 1988; ZÁrATE \& BlASI 1991) suggests that volcanism in the Andean region was the predominant process of particle formation, specifically, as a generator of pyroclastic deposits that were reworked by erosive fluvial processes, wind, and glaciers. GARDENAL (1986) describes four main groups of wind geoforms in the western part of Buenos Aires province. The calibration of these episodes is difficult. According to ZÁRATE \& Blasi (1991), the first two episodes correspond to the end of the Pleistocene, while the third occurred in the middle Holocene, and the last during historical times. On the contrary, the Luján Formation is represented mainly by floodplain deposits that are widely developed along with the main river systems in Buenos Aires province (FIDALGo etal. 1973). The lower layer of the Luján Formation corresponds largely to the fluvial deposits (the La Chumbiada and Guerrero members), while the upper layers are essentially lacustrine (the Río Salado Member). Two edaphic stratigraphic units are recognized. The first one called the paleosoil Puesto Callejón Viejo that develops in the upper part of the Guerrero Member, and the second, known as paleosoil Puesto Berrondo, developed in the upper part of the Río Salado Member (FIDALGO etal. 1991; Bonadonna etal. 1995). The last paleosoil indicates a higher moisture regime that could coincide with a higher sea level moment, manifested by the marine ingression recorded around 5000-6000 yrs BP (SCHNACK 1987; ZÁRATE \& Flegenheimer 1991). Prior to this, another marine transgression associated with MIS 5e, called Pascua Formation, was described for the coastal zone (FidALGo etal. 1973; IsLA etal. 2000; SchNaCK etal. 2005).

\subsection{Local framework}

Fossil equids described in this paper came from two stratigraphic profiles along the Tapalqué creek. One of these is the outcrop at Avellaneda Bridge locality, located in the center of the Olavarría City, and the other is the Salto de Piedra locality, about $8 \mathrm{~km}$ outside the city (Fig. 1). At Salto de Piedra locality, six depositional unit separated by discontinuities (alounits) have been recognized. They represent the Late Quaternary stratigraphic sequence that outcrops along the upper basin of the Tapalqué creek (see also Orgeira et al. 2001).

- Depositional Unit I comprise very pale brown (10YR 7/3) silty sand deposit with subordinate gravel (rounded fragments of calcium carbonate composition). A well-developed calcrete (about $25 \mathrm{~cm}$ thick) crowns the top of the unit. Below this calcrete, matrixsupported massive gravel (diamict), horizontal layers of gravel and fine sand and irregular carbonate nodules predominate. Vertebrate remains are relatively abundant as well as crotovinas. This unit corresponds to the Middle Pleistocene (>120 ky BP) colluvial and fluvial deposits and broadly correlate with the upper level of the Pampiano Formation (FIDALGo et al. 1973).

- Depositional Unit II to IV are brownish yellow to very pale brown (10YR 6/6 to $10 \mathrm{YR} 7 / 3)$ sandy silt to sandy gravel deposits, with trough cross and horizontal bedding structure. Vertebrate remains and small freshwater gastropods (e.g., Succinea meridionalis, Heleobia parchapii, Biomphalaria peregrina) are abundant in some layers. These species inhabit lotic and lentic environments, adhered to algae or rocks (Gaillard \& Castellanos 1976). Succinea meridionalis has hydrophilic habits, related to humid soils or saturated water. These units correspond to Late Pleistocene fluvial deposits (ca. $>21$ to $11 \mathrm{ky} \mathrm{BP}$ ), which may be correlated to the Guerrero Member of the Luján Formation (FIDALGO etal. 1973).

- Depositional Unit $\mathrm{V}$ comprises a light gray to gray $(2.5 \mathrm{Y} 7 / 1$ to $2.5 \mathrm{Y} 6 / 1)$ silty deposit with horizontally laminated to massive structure and lenticular geometry. The malacological association is characterized by the same freshwater gastropods present in Unit II to IV. This unit corresponds to Early/Mid Holocene fluvial-lacustrine deposits (ca. 11 to $4 \mathrm{ky} \mathrm{BP}$ ) which may be correlated to the Río Salado Member of the Luján Formation (FidALGO et al. 1973).

- Depositional Unit VI is a dark grayish brown $(2.5 \mathrm{Y}$ 4/2) sandy silt deposit with granular structure. These sediments were affected by pedogenesis in the form of a dark soil (Mollisol), well-drained, which differentiates an A-AC-C profile (Figs. 2, 3). This unit corresponds to edaphic alluvial Late Holocene deposits. 


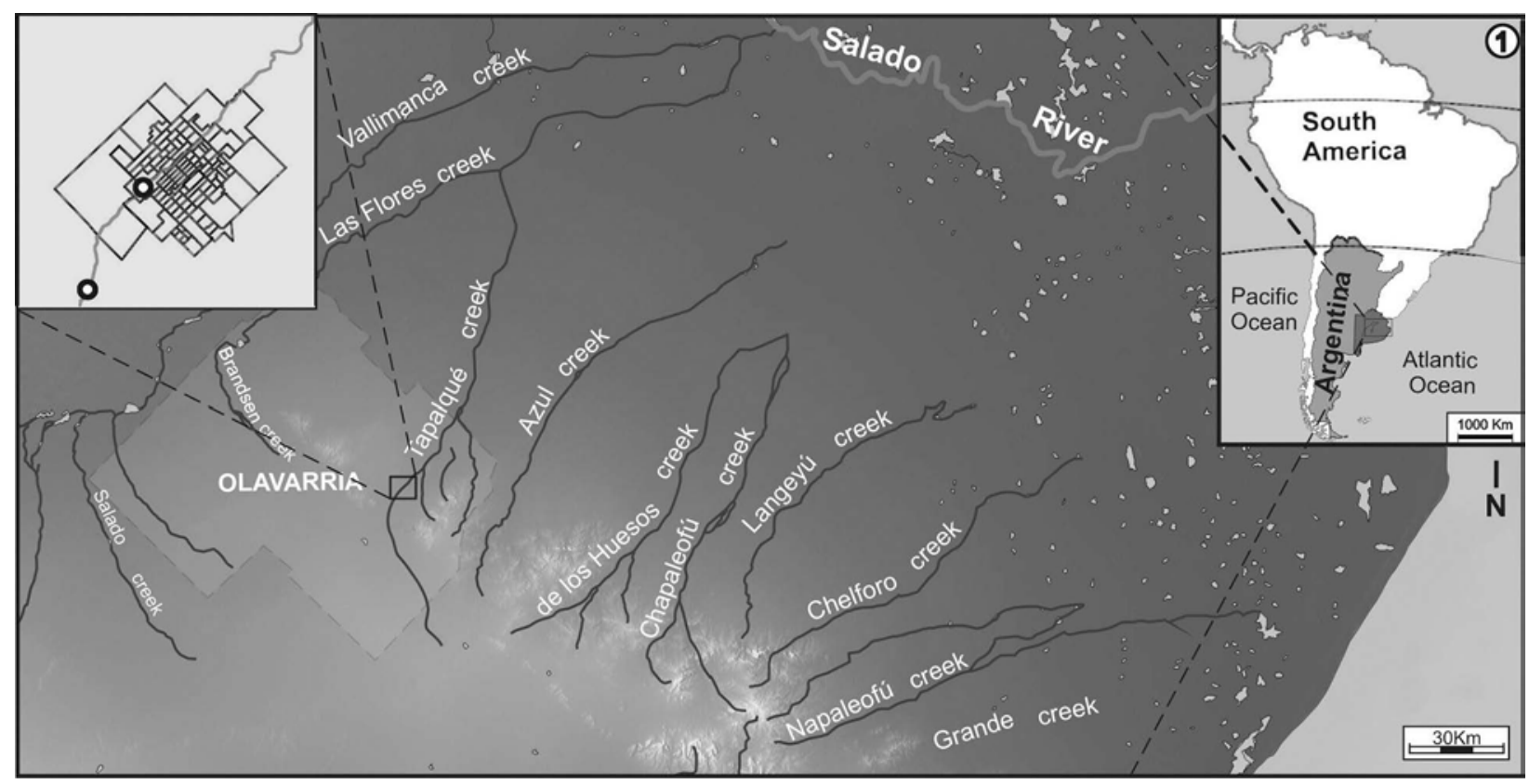

Fig. 1. Location map showing the sampling site.

\section{Biostratigraphy}

FLORENTINO AMEGHINO established the reference standard for the continental Cenozoic of South America and proposed a sequence of ages grouped into higherorder units (AMEGHINo 1889; AMEGHINo 1906). This scheme, with its subsequent modifications, is still valid today to establish a chronology of the region (CiOne etal. 2007). Until the 1940s there was great confusion, because the same names were used to distinguish rock, time, and faunal units. SIMPSON (1940) and PASCUAL etal. $(1965,1966)$ established a certain order by proposing a South American Land Mammal Age scheme (SALMA) based on the continental sequences of mammals. These ages were established through the evolutionary degree of the faunas, in part following the same way as AMEGHINO. Although these units have not been recognized by any stratigraphic code, they have proved to be very useful as an organizational method in the development of concepts about the stratigraphy and evolution of mammals (SIMPSON 1971; Pascual \& Ortiz Jaureguizar 1990). Pascual etal. (1996) suggested that SALMA has proved to be useful for intra- and intercontinental correlations and subdividing Cenozoic time.

Recently, Cione \& TonNi (2005) proposed a new biostratigraphic framework involving the continental sediments and faunas of the Pampean region, from the Late Miocene to the present. These authors recognized 13 biozones for this interval, which represent the biostratigraphic basis for the recognition of stages and substages in the Pampean Region. In this paper, we follow both of these criterions to establish the chronological position of the horses. The sediments attributed to the Lujanian Age that are stratigraphically correlated with the Equus neogeus Biozone (sensu Cione \& Tonni 2005), would be represented, in the Pampean region, by the lower part of the Luján Formation (Guerrero Member). This unit was deposited during the interval between ca. 21 and $11 \mathrm{ky}$ BP (TonNi et al. 2003), preliminary ${ }^{14} \mathrm{C}$ from both profile extend this interval to 35.3 and $10.1 \mathrm{ky}$ BP (Table 1).

\section{Material and methods}

The material under study is deposited in the INCUAPA-CONICET, Faculty of Social Sciences of the National University of Central Buenos Aires. It is an incomplete skull of Equus (FCS-P.10.1.1) coming from the Tapalqué creek profile near the bridge of Avellaneda avenue in Olavarría. Several remains assigned to Hippidion coming from Salto de Piedra profile, specifically: one M1-2 right (FCS-P.8), one distal epiphysis of 


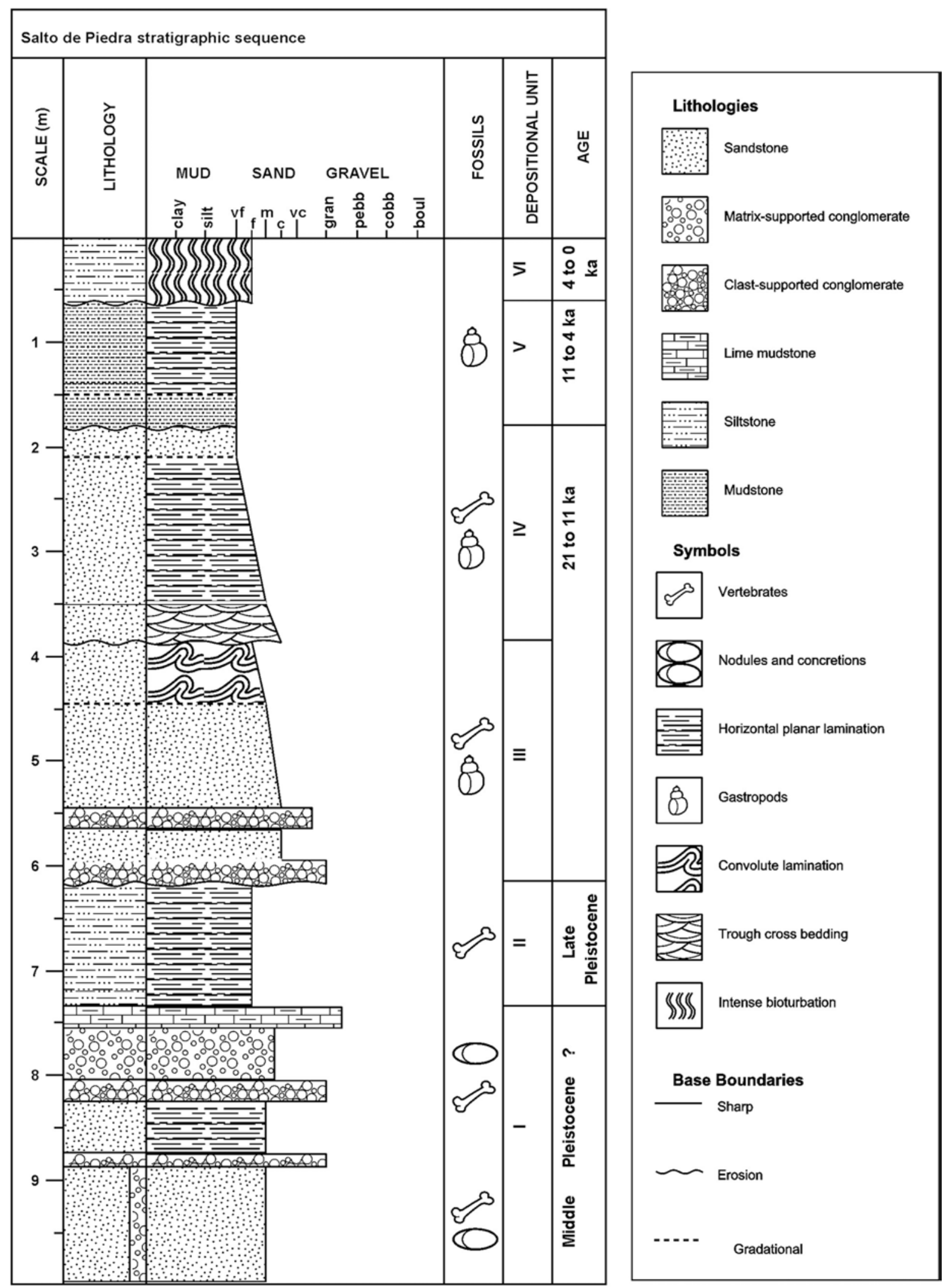

Fig. 2. Profile representing the sedimentary succession exposed on sequences outcropping along of the Tapalqué River. 


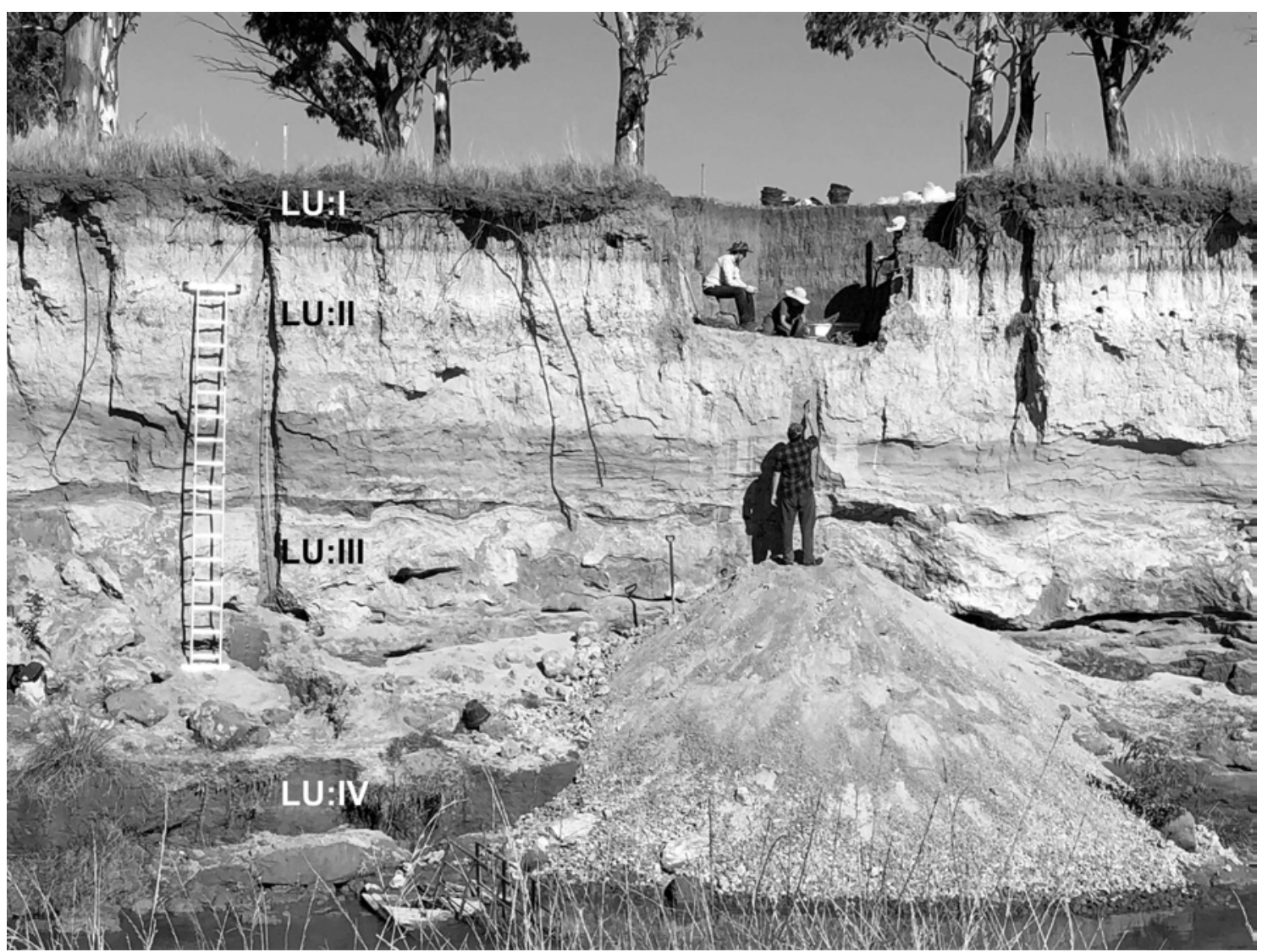

Fig. 3. Detail of the excavation and profile at the Salto de Piedra site.

Table 1. ${ }^{14} \mathrm{C}$ ages from the studied profiles. ${ }^{*}$ Calibrated age with Calib 7.1 with two sigma, curve SHCal04 (HoGG etal. 2013; Stuiver etal. 2019).

\begin{tabular}{|c|c|c|c|c|c|c|c|}
\hline $\begin{array}{l}\text { Lab } \\
\text { number }\end{array}$ & Sample & Profile & $\begin{array}{l}\text { 14C age } \\
(14 \mathrm{C} \mathrm{ka} \mathrm{BP})\end{array}$ & $\begin{array}{l}14 \mathrm{C} \text { age cal. } \\
\text { AP* }\end{array}$ & $\begin{array}{l}\text { Median } \\
\text { Unit }\end{array}$ & & Reference \\
\hline LP-395 & S. meridionalis & Salto de Piedra & $8810 \pm 140$ & $9535-10,187$ & 9830 & $\mathrm{~V}$ & Figini etal. 1995 \\
\hline \multirow[t]{2}{*}{ LP-379 } & S. meridionalis & Salto de Piedra & $9710 \pm 110$ & $10,693-11,256$ & 10,993 & $\mathrm{~V}$ & Figini etal. 1995 \\
\hline & Biomphalaria sp. & Salto de Piedra & $9,850+350-340$ & $10,296-12,405$ & 11,284 & $\mathrm{~V}$ & Bonadonna etal. 1995 \\
\hline $\begin{array}{l}\text { GrA- } \\
49131\end{array}$ & $\begin{array}{l}\text { Smilodon } \\
\text { populator }\end{array}$ & Salto de Piedra & $\begin{array}{l}10,140 \pm 60 \\
(\mathrm{AMS})\end{array}$ & $11,363-11,974$ & 11,673 & IV & Prado etal. 2015 \\
\hline \multirow{2}{*}{$\begin{array}{l}\text { GrA- } \\
47178\end{array}$} & Equus neogeus & Salto de Piedra & $13,590 \pm 60(\mathrm{AMS})$ & $16,091-16,567$ & 16,318 & III & Prado etal. 2015 \\
\hline & L. parchappei & Salto de Piedra & $19,930+650-600$ & $22,496-25,474$ & 23,955 & III & Bonadonna etal. 1995 \\
\hline \multirow[t]{5}{*}{ LP-396 } & L. parchappei & Salto de Piedra & $21,040 \pm 450$ & $24,154-26,080$ & 25,218 & III & Figini etal. 1995 \\
\hline & L. parchappei & Salto de Piedra & $21,940 \pm 230(\mathrm{AMS})$ & $25,715-26,684$ & 26,147 & III & Bonadonna etal. 1999 \\
\hline & L. parchappei & Avellaneda & $27,980+1500-1350$ & $28,957-34,803$ & 32,047 & III & Bonadonna etal. 1999 \\
\hline & L. parchappei & Avellaneda & $34,500 \pm 100(\mathrm{AMS})$ & $38,585-39,281$ & 38,908 & III & Bonadonna etal. 1999 \\
\hline & L. parchappei & Avellaneda & $\begin{array}{l}35,300+1300-1100 \\
(\mathrm{AMS})\end{array}$ & $36,677-42,051$ & 39,681 & III & Bonadonna etal. 1999 \\
\hline
\end{tabular}


humerus (FCS-P.91.1), one magnum left (FCS-P.91.5), one scaphoid left (FCS-P.91.4), one lunatum left (FCS-P-91.3), one pyramidal left (FCS-P.91.6), one MCIII left (FCS-P.91.2), one distal epiphysis of tibia right (FCS-P.5), one first phalanx of the central digit (FCS-P.29). Plus, two remains from lower level V of Salto de Piedra that appeared next to a tooth, may correspond to Hippidion: one m1-2 left (FCS-P.130) and one proximal epiphysis of MTIII left (FCS-P.8).

Determination of the skull remains was made on a comparative study with other skulls from different South American localities. Morphometric and comparative analysis of the MCIII and 1PHIII was made using a large database already utilized in previous works (Prado \& Alberdi 1994; Alberdi \& FrassinetTi 2000; Alberdi etal. 2003; Alberdi \& Prado 2004; Prado etal. 2005; Rincón etal. 2006; Prado \& ALBERDI 2008; PRADO \& AlbERDI 2012). To classified the new remains we used the discriminate analysis (DA) that allowed us to know the affinity of the new elements with the previously established groups. The DA matrix of skeletal measurements is based on $31 \mathrm{MCIII}$ and 83 1PHIII. The nomenclature and measurements are based on the recommendations and rules elaborated by the "Hipparion Conference" (EIsENMANN etal. 1988). All dimensions are in millimeters. The statistical package SPSS 15.0 was used for these analyses.

Taphonomic studies provide evidence on the preservation processes and how they affect the information on the fossil record (BEHRENSMEYER \& KIDWELL 1985 ) and is a primary step in paleoecological and paleoenvironmental research (ANDREWs 1995; HART 2012). Taphonomic studies in faunal assemblages are important nowadays due to the possibility of knowing the biostratinomic and diagenetic processes that acted on them (ANDREws 1990; LyMAN 1994). New methodological tools have been developed as a result of access to more sophisticated technologies (Scanning Electron Microscope, among others) that, together with experimental studies, provide new ways of investigating the integrity of fossil assemblages (DAUPHIN \& BRUGAL 2013). Recognition of site formation processes that could have disturbed the original assemblages enables the degree of bias in the faunal composition to be corrected, leading to a better understanding of the relationship between the living and fossil environment and a more precise paleoenvironmental interpretation (WeIGelt 1927; EFREMOV 1940; BeHRENSMEYER 1978; ANDREws 1990; FernÁndEZ-JALVo et al. 2010).

In this study, we analyzed the taphonomic of bones horses using the following variables:
Degree of weathering: the six stages defined by BEHRENSMEYER (1978) for macromammals were evaluated: stage 0 represents remains with no evidence of weathering; stage 1 cracking parallel to fiber structure; stage 2 concentric flaking associated with cracks, with loss of most of the outer bone; stage 3 altered compact bone resulting in fibrous texture; stage 4 coarsely fibrous and rough surface, splinters of bone loose on surface; stage 5 bone falling apart in situ with large splinters lying around indicates an extreme degree of weathering. For micromammals, it was evaluated by the four stages defined by ANDREws (1990): stage 0 no modifications; stage 1 slight splitting on bone parallel to fiber structure chipping of teeth and splitting of dentine; stage 2 more expansive splitting on bone and teeth leading to loss of parts of crown; stage 3 deep splitting and some loss of deep segments or flakes and extensive splitting teeth.

Degree of abrasion: This was analyzed according to the three categories proposed by Alcalá (1994): category 0 : remains with intact surfaces; category 1 : remains with rounded edges, and category 2 : remains with polished external surfaces.

Degree and type of breakage: The degree of breakage was evaluated based on whether the remains were complete or incomplete. The types of fracture were evaluated only for long bones, following the classification proposed by MARSHALL (1989).

Degree of bioerosion: This was assessed based on the presence of modifications caused by two kinds of bio erosive trace fossils were recognized. One of them is due to root growth on the bone element sediment interface and the second kind of trace fossil is due to soil fungal and/or bacterial activity the mechanical action of other organisms (LYMAN 1994; BEHRENSMEYER etal. 1989; Mikuláš 1999; Montalvo 2002; Montalvo 2004; Tomassini \& Montalvo 2013).

The presence of manganese deposition is related to an environmental condition characterized by wet, mildly alkaline and oxidizing, as well as the involvement of bacteria (COURTY etal. 1989; LóPEZ-GonZÁLEZ etal. 2006; FernándeZ-Jalvo \& Andrews 2016). The calcium carbonate encrustations are mainly due to the precipitation of these salts on the surface of the bones by water filtration (LYMAN 1994).

The other taphonomic variables recorded are trampling and flakering (ANDREws 1990; BEHRENSMEYER 


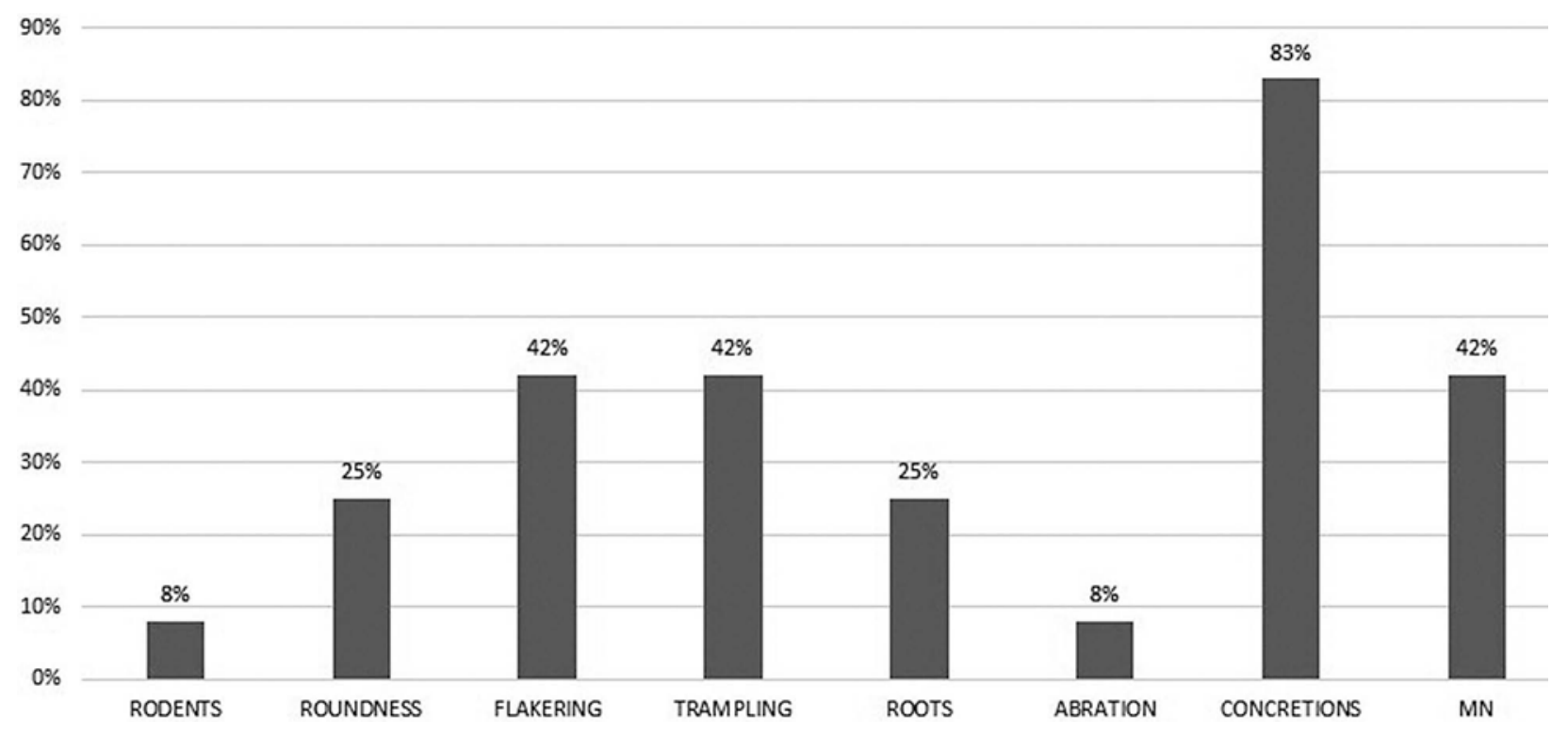

Fig. 4. Taphonomic variables identified on horse bones from Tapalqué creek.

1978; DenYs et al. 1996; Denys etal. 1997), these variables are related to soil movements or fossil diagenesis agents like water transport or eolian modifications (VOORHIEs 1969; DodSON 1973; KORTH 1979)

Abbreviations: $\mathrm{P} / \mathrm{M}$, upper premolars and molars; $\mathrm{p} / \mathrm{m}$, lower premolars and molars; MTIII and MCIII, third metacarpal or metacarpal of the central digit; 1PHIII, first phalanx of the central digit; Col.num., Collection number; DA, discriminant analysis; L trans, transversal length; L a-p, antero-posterior length; H, height; G, thickness; AP, proximal articulation; $\mathrm{AD}$, distal articulation.

\section{Taphonomy}

We analyzed thirteen horse bone elements and the only complete long bone, a metacarpal. The rest of the skeletal parts are fractured; they correspond to long bones and cranial bones, with dry fractures with irregular edges.

According to the variables considered, evidences of flaking and trampling are the most numerous (42\%). The manganese stains are present $(42 \%)$ and cover the entire bone surface. The calcium carbonate is present in $83 \%$ of the sample. Another variable considered is roundness $(25 \%)$ which, principally, may be the result of water action on the bone surface. The percentage of abrasion registered is $8 \%$ (Fig. 4) which is low but it is still important since within the scale proposed by ALCALÁ (1994) they generally fall within the scale 1 and 2, which indicate that certain elements have been subject to significant abrasion, probably due to water transport. The abrasion can be associated with $25 \%$ of registered rounded elements, especially in the acute edges of the epiphyses that are smoothed, which correspond to small-sized elements such as tarsal bones, teeth or phalanges. Concerning bioerosion produced by other organisms, $25 \%$ have root marks, and $8 \%$ indicate the activity of rodents.

In general, the bone assemblages found along the Tapalqué creek are very well preserved, perhaps due to rapid burial and little exposure to the weather. The highest percentage of weathered elements corresponds to stage 1 (sensu BeHRENSMEYER 1978), characterized mainly by cracking parallel to fiber structure, and in some cases articular surfaces with mosaic cracking. Another feature observed is exfoliation on the surface, which may be caused by abrasion. Only $9 \%$ of the material with weathering reaches stage 2 , which presents a greater amount and depth in the longitudinal fractures and a marked exfoliation on the surface of the bones. The precipitation of calcium carbonate salts in some cases it is difficult to remove and the bone surface is covered by these concretions (Fig. 4), in some cases the calcium carbonate covers partially the bone surface, while in other bones, principally small ones like phalanges or autopodial, it covers almost entirely the bone surface. The fluvial transport can bury or move the bones; this 


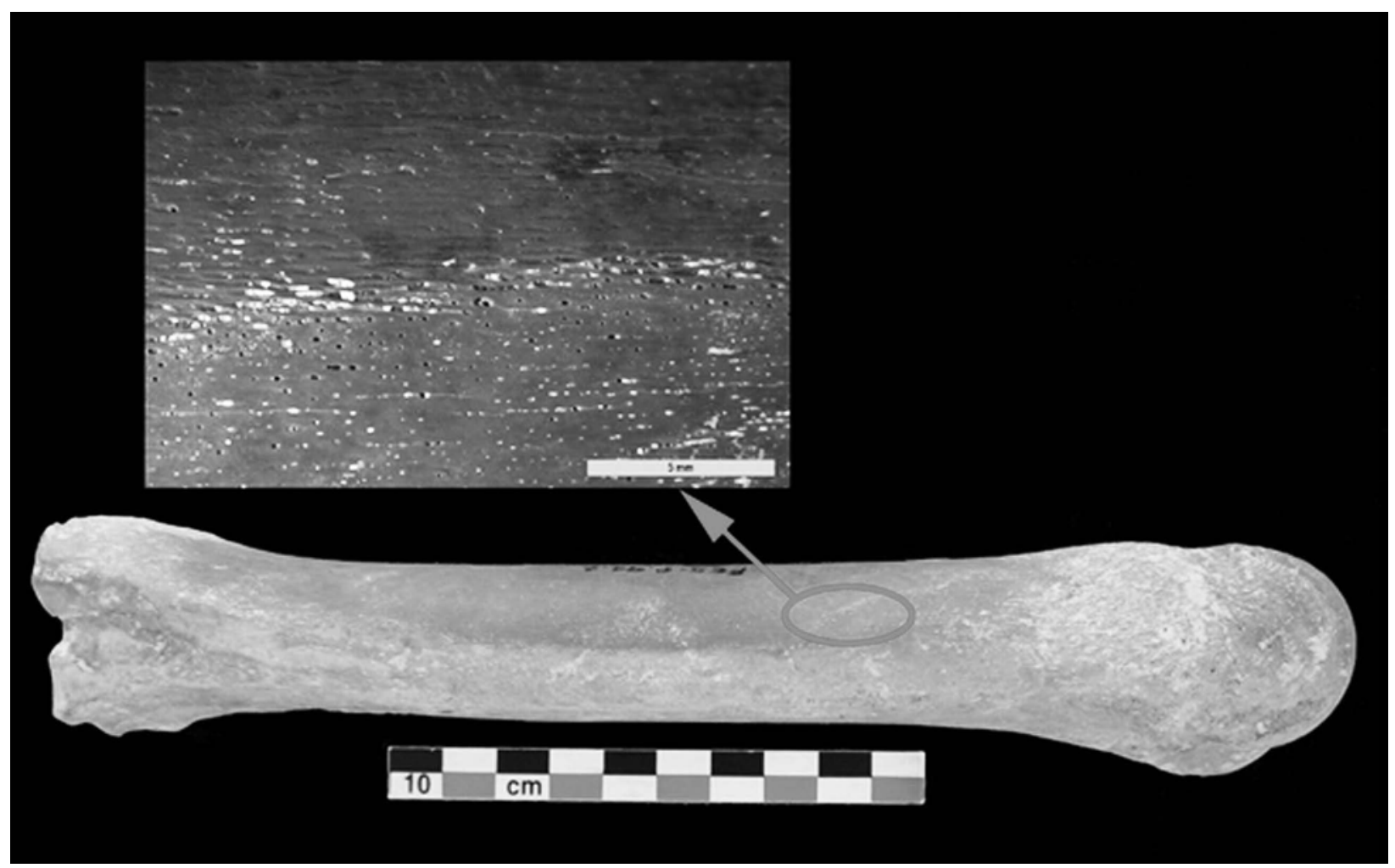

Fig. 5. Horse metatarsal wherein some areas of the diaphysis appear polished, on left superior picture the area detailed appears the difference between the surfaces, in one can it see the normal surface above and the surface polished below. Other taphonomic characteristics that can be observed on the metatarsal are the calcite incrustations, not only on the surface, but also inside the bone tissue.

action can be reflected by the broken bones, especially when the sediments are coarse. Some bones have their surfaces, partially or entirely, polished (25\%; Fig. 5).

The faunal assemblage has undergone intensive fossil diagenetic modifications, especially those that have favored a drag of certain skeletal parts; however, the small distal parts have not managed to be damaged, unlike the long bones, which generally have taphonomic fractures and alterations produced by trampling, and polishing probably by the action of water.

The distal epiphysis of humerus (FCS-P.91.1) belongs to a juvenile individual; this is reflected in the distal portion that show evidence of unfused bone; it can be described as depression on the bone surface similar to a cut mark, but deeper on the limit of the unconsolidated surface and the humerus diaphysis. This element must be analyzed and compared because there could be evidence of a wound with an infectious process with the consequences of not finishing the ossification process in that portion (Fig. 6).

\section{Systematic paleontology}

In 1950, the French paleontologist ROBERT HOFFSTETTER created the subgenus Amerhippus to include all species of the genus Equus from South America. The author justified this subgenus by a single character: the absence of infundibulum along the surface of the lower incisors and, therefore, the loss of enamel on the chewing surface. In a later work on the revision of mammals from Ecuador, HofFsteTter (1952) indicated that the ulna is stronger in the South American horses than in other Equus. In the literature, the recognition of the subgenus Amerhippus is controversial. Recently, PRADO \& AlBERDI (2017) questioned the use of the subgenus Amerhippus. OrLANDO etal. (2008) conducted DNA-based phylogenetic analyses revealing that all Pleistocene South American species of Equus were members of the caballine horse lineage, not a distinct subgenus as first suggested by HOFFSTETTER (1950). Therefore, the validity of the subgenus Amerhippus is questionable and is not employed herein. 


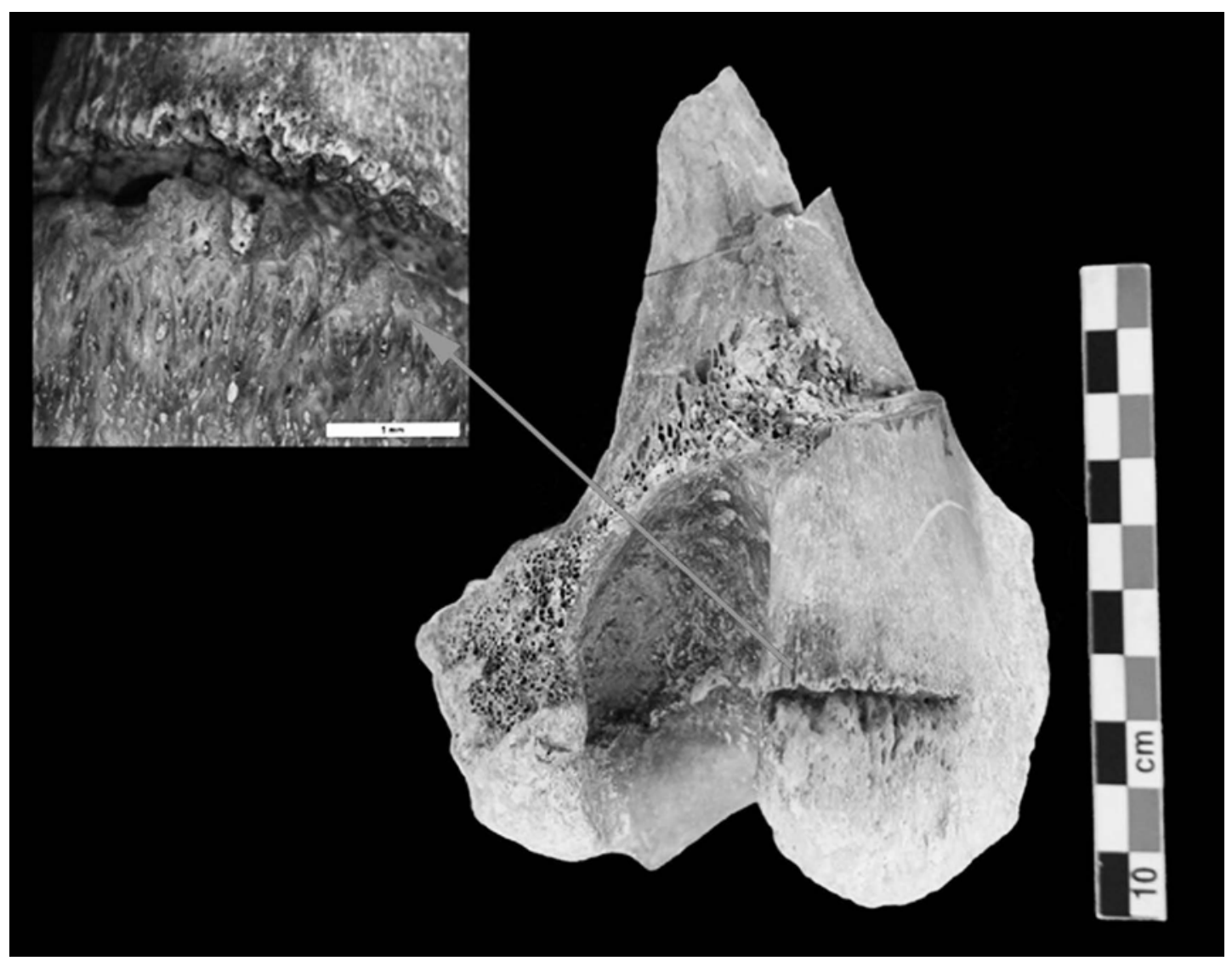

Fig. 6. Distal part of a humerus with a scare of a wound on the condyles. This element belongs to a juvenile individual. The detailed picture (top left) shows the characteristics of the wound and part of not solder with the rest of the bone. Probably this wound suffered an infectious process.

Order Perissodactyla Owen, 1848

Family Equidae GraY, 1821

Subfamily Equinae GraY, 1821

Tribe Equini GraY, 1821

Subtribe Pliohippina Prado \& AlBERDI, 1996

Genus Equus Linnaeus, 1758

Equus neogeus Lund, 1840

\section{Fig. 7}

Synonymy: See Prado \& Alberdi (2017).

Holotype: Right metacarpal III, number 866, stored in Zoologisk Museum, PETER W. LuND Collection, Copenhagen, Denmark.

Geographic distribution: Main remains came from the Pampean Region, Argentina; others from Lagoa Santa (Lund 1840), Corumba (CunHa 1981), Sao Raimundo Nonato, Piaui (Guérin 1991), Chique-Chique, Aguas do Araxa (Paula Couto 1979), and Cota dos Ossos (AlberDI et al. 2003) in Brazil; and Arapey Grande creek and So- pas Creek in the Sopas Formation, Uruguay (UBiLLA etal. 2004); Cerro Gordo (PorTa 1960) and Tibitó (CORREAL URREGO 1981), Colombia.

Stratigraphic distribution: Upper Pleistocene of Buenos Aires province, Argentina, Brazil, Colombia, and Uruguay. PORTA (1960) correlated Cerro Gordo (Colombia) with the Punian in Ecuador (sensu HoffSTETTER 1952).

Type horizon: Lujanian Land Mammal Age.

Studied material: A large skull (Fig. 7) that lacks the symphysis and the dorsal part including the left orbit and the paraoccipital processes (FCS-P.10.1.1).

Description: The skull is not complete, lacks the symphysis and the anterior dentition. The two complete dental rows are preserved, $\mathrm{P} 2-\mathrm{M} 3$ right and left, in a state of medium wear, no presence of P1. The dentition presents the premolars greater than the molars. The premolars with wide styles and molars with fine ones. The enamel wrinkles reduced, with triangular protocone except in P2, which is more oval, with a slight lingual cleft and a marked caballin fold in the premolars while in the molars are being lost. The hypoconus is 


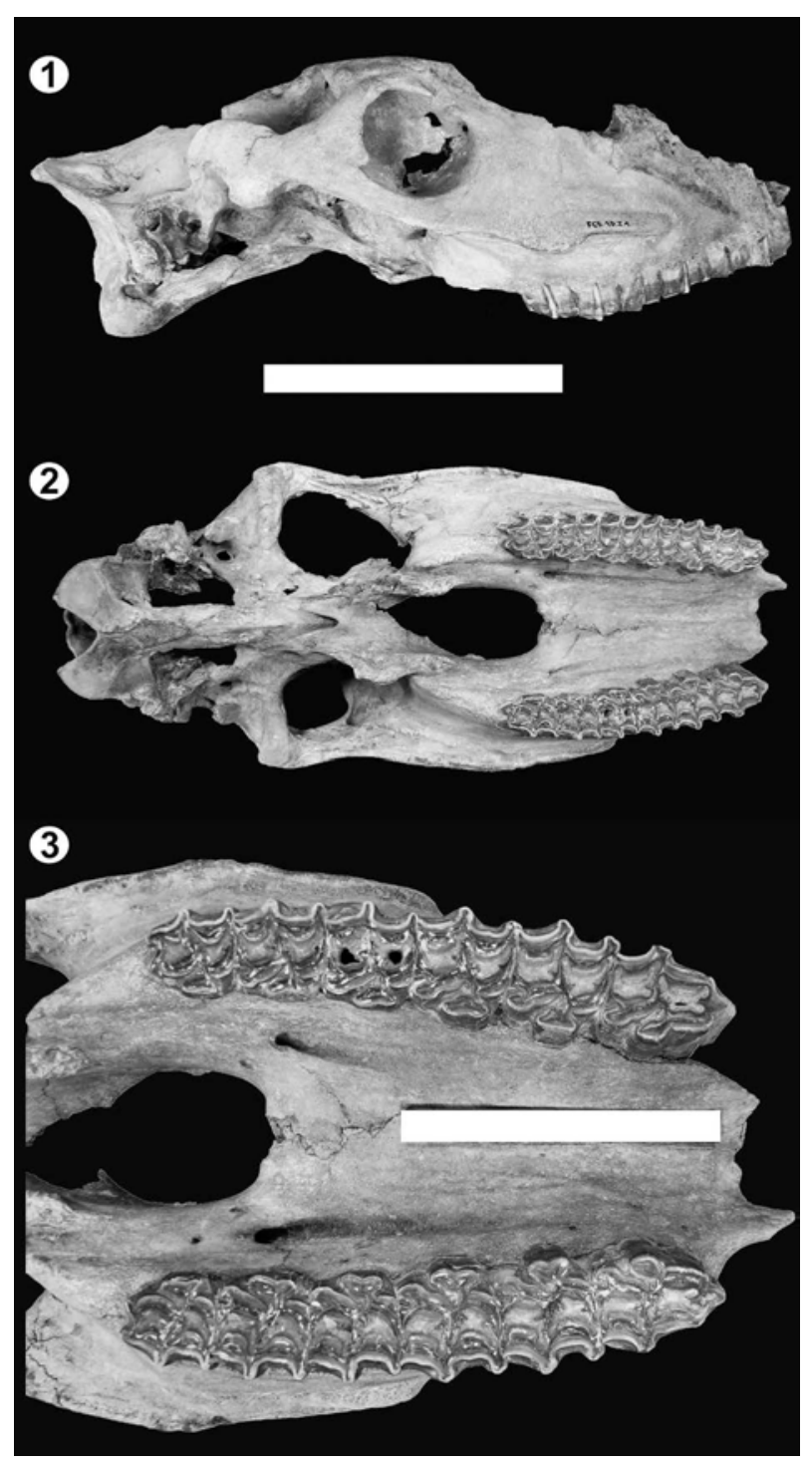

Fig. 7. Skull of Equus neogeus from the Avellaneda avenue profile. 1 - Lateral view right; $\mathbf{2}$ - ventral view; $\mathbf{3}$ - detail of dentition. Scales: Figs. 1 and $220 \mathrm{~cm}$; Fig. $310 \mathrm{~cm}$.

open with large distal sinus and lingual reduced to a notch except in the M3, where the hypoconus is very retracted with the distal and buccal sinuses marked (measurements of the dentition in Table 2; Fig. 7). The measurements of the skull that can be taken are: palatal length $139 \mathrm{~mm}$, vomer length $122 \mathrm{~mm}$, post-vomer length $127 \mathrm{~mm}$, post-palatal length $240 \mathrm{~mm}$, premolar row length $92.8 \mathrm{~mm}$ both the right and the left, molar row length $75.4 \mathrm{~mm}$ right and $74.6 \mathrm{~mm}$ left, P2-M3 row length $166 \mathrm{~mm}$ right and $164 \mathrm{~mm}$ left, choana length $72 \mathrm{~mm}$ ca, minimal breadth of the choana $35.2 \mathrm{~mm}$ and maximal breadth of the choana $43.6 \mathrm{~mm}$, palatal breadth at level of P4-M1 $77 \mathrm{~mm}$, length of fossa temporalis maximal right $82 \mathrm{~mm}$ and left $87 \mathrm{~mm}$, length between the edge of the fora- men magnum (basion) and the foramen ethmoidal $176 \mathrm{~mm}$, frontal breadth $>190 \mathrm{~mm}$, bizygomatic breadth $199 \mathrm{~mm}$, occipital breadth $69.4 \mathrm{~mm}$, occipital height $72 \mathrm{~mm}$, posterior ocular line $222 \mathrm{~mm}$, exterior height of the meatus auditive externus $13 \mathrm{~mm}$, anterior-posterior orbital diameter $62 \mathrm{~mm}$, orbital diameter perpendicular to the former $55 \mathrm{~mm}$, height of back of the foramen infra-orbital above the alveolar border $67 \mathrm{~mm}$.

Genus Hippidion Owen, 1869

Hippidion devillei (GERVAIS, 1855)

Fig. 9

Synonyms: See Prado \& Alberdi (2017).

Holotype: The material figured by GervaIs (1855, pl.7, figs. 11, 12 (the left P2M3 row fragment and right astragalus). Institut de Paléontologie IPMNHN, Paris (France).

Type locality: Uquía, Jujuy, Argentina.

Geographic distribution: Esquina Blanca in Uquía and Barro Negro in Jujuy, San Luis, Uspallata in Mendoza (CERDEÑo etal. 2008) and several localities of the Buenos Aires province (Argentina). In Santana and Toca dos Ossos in the Bahia State and in the Lagoa Santa area in Mina Gerais State in Brazil (ALBERDI etal. 2003). Tarija and Ulloma in Bolivia, and Tirapata in Perú.

Stratigraphic distribution: Late Pliocene to Pleistocene, Uquian to Lujanian SALMA.

Studied material: Distal epiphysis of humerus (FCS-P.91.1); left magnum (FCS-P.91.5); left scaphoid (FCS-P.91.4); left lunatum (FCS-P-91.3); left pyramidal (FCS-P.91.6); left MCIII (FCS-P.91.2), distal epiphysis of right tibia (FCS-P.5) and first phalanx of the central digit (FCS-P.29).

Description: The remains of the appendicular skeleton seem to correspond to young individuals; the sutures of their epiphyses are still observed, which suggests that they correspond to the same individual. The distal epiphysis of the humerus is quite robust (measurements in Table 3). The magnum, scaphoid, lunatum, and pyramidal of left talus are very well preserved, (measurements in Table 3). The MCIII is relatively small and slender, it corresponds to a young individual by the sutures of his epiphyses, which are clearly observed and more pronounced in the distal end than in the proximal (this could indicate an increase in its final size). The fingerprint of the fingers sides exceeds in length to the midpoint of the diaphysis. The distal epiphysis of a right tibia is also robust (measurements in Table 3 ). A very robust 1 PHIII is observed, typical of Hippidion, with its strong muscular insertions on the posterior side, even with a faint line corresponding to the proximal epiphysis footprint (Table 3). MCIII and 1PHIII have been included them in their respective DA with the groups of Hippidion species already studied, in order to observe which of them are best associated. Results of DA indicate that the analyzed specimen of MCIII was identified to the Hippidion saldiasi group with a correct previous classification of $94.3 \%$ and $74.3 \%$ by cross-validation, but it is placed among the remains of $H$. devillei (see Fig. 8, top diagram). Possibly this is a con- 

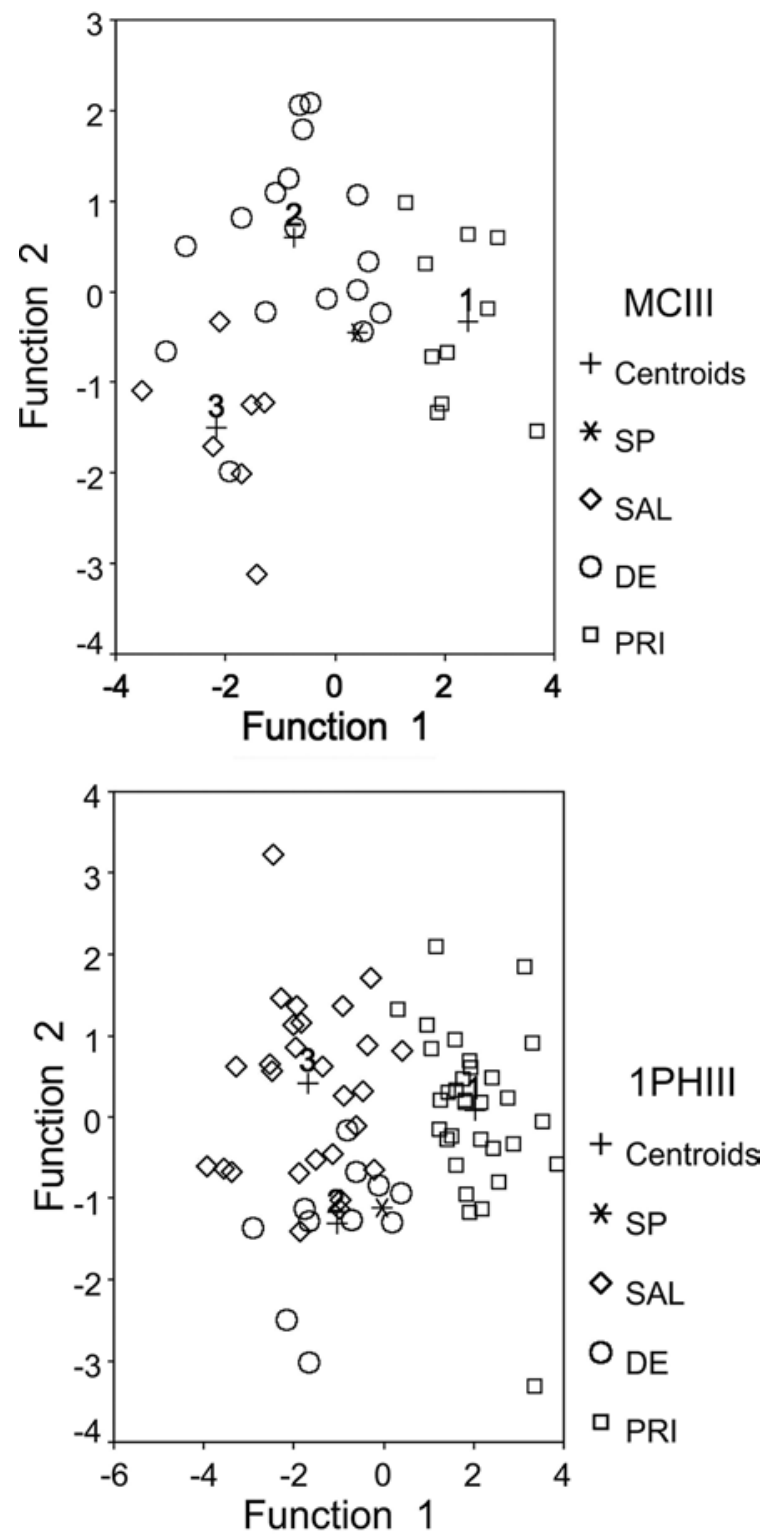

Fig. 8. Discriminant Analysis (DA) of MCIII and 1PHIII of Hippidion. Abbreviations: SP, remains from the Salto de Piedra; SAL, Hippidion saldiasi; DE, Hippidion devillei; PRI, Hippidion principale. In the first diagram, the asterisk of the MCIII of Salto de Piedra is located next to the other metacarpals of Hippidion devillei.

Fig. 9. Remains of Hippidion devillei from the Salto de Piedra profile. 1 - Distal part of humerus in anterior view; $\mathbf{2}$ - proximal facets of MCIII; 3 - MCIII in anterior view; 4 - MCIII in posterior view; 5 - 1PHIII in anterior view; $\mathbf{6}$ - 1PHIII in posterior view; 7 - distal articulation of tibia; 8 - upper M1-2 right in occlusal view of Hippidion principale. Scales: Figs. 1, 2, 5, 6, and 7: $3 \mathrm{~cm}$; Figs. 3 and 4 $10 \mathrm{~cm}$; Fig. $83 \mathrm{~cm}$.

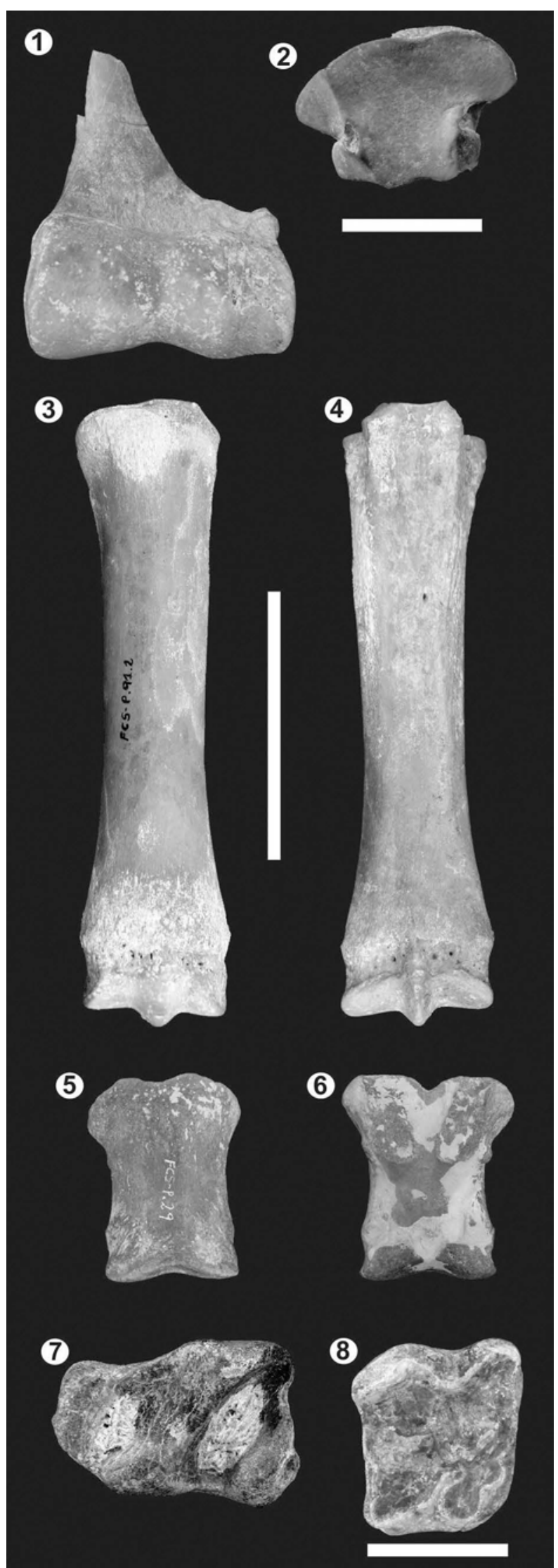


Table 2. Measurements of Equus neogeus and Hippidion principale teeth from the Avellaneda and Salto de Piedra profiles. All dimensions are expressed in millimeters. Abbreviations: Ls, occlusal length; Bs, occlusal breadth; Lb, length of the tooth a $1 \mathrm{~cm}$ from the roots; $\mathrm{Bb}$, breadth of the tooth at $1 \mathrm{~cm}$ distance from the roots; PrL, occlusal length of the protocone; postfl., occlusal length of the postflexid.

\begin{tabular}{|c|c|c|c|c|c|c|c|c|c|c|}
\hline Col.num. & $\begin{array}{l}\text { Type of } \\
\text { tooth }\end{array}$ & Species & Locality & Ls & Bs & Height & PrL & Pr shape & $\begin{array}{l}\text { Pli } \\
\text { caballin }\end{array}$ & $\begin{array}{l}\text { plis } \\
\text { fossettes }\end{array}$ \\
\hline FCS-10.1.1 & P2 right & Equus neogeus & $\begin{array}{l}\text { Avellaneda } \\
\text { street }\end{array}$ & 37.4 & 25.2 & in jaw & 7.8 & oval short & 1 & $1 / 41 / 1$ \\
\hline FCS-10.1.1 & P3 right & Equus neogeus & $\begin{array}{l}\text { Avellaneda } \\
\text { street }\end{array}$ & 28.8 & 29.0 & in jaw & 11.0 & triangular & 1 & $1 / 21 / 1$ \\
\hline FCS-10.1.1 & P4 right & Equus neogeus & $\begin{array}{l}\text { Avellaneda } \\
\text { street }\end{array}$ & 28.9 & 28.8 & in jaw & 13 & triangular & 1 & $1 / 52 / 1$ \\
\hline FCS-10.1.1 & M1 right & Equus neogeus & $\begin{array}{l}\text { Avellaneda } \\
\text { street }\end{array}$ & 24.5 & 27.0 & in jaw & 12.4 & broken & 1 & 0/4 2/slot \\
\hline FCS-10.1.1 & M2 right & Equus neogeus & $\begin{array}{l}\text { Avellaneda } \\
\text { street }\end{array}$ & 23.5 & $25 \mathrm{ca}$ & in jaw & $13 \mathrm{ca}$ & triangular & slot & $0 / 22 / 1$ \\
\hline FCS-10.1.1 & M3 right & Equus neogeus & $\begin{array}{l}\text { Avellaneda } \\
\text { street }\end{array}$ & 27.0 & 23.5 & in jaw & 12.8 & triangular & slot & slot/3 2/0 \\
\hline FCS-10.1.1 & P2 left & Equus neogeus & $\begin{array}{l}\text { Avellaneda } \\
\text { street }\end{array}$ & 37.0 & 26.2 & in jaw & 9.0 & oval short & 1 & $1 / 53 / 1$ \\
\hline FCS-10.1.1 & P3 left & Equus neogeus & $\begin{array}{l}\text { Avellaneda } \\
\text { street }\end{array}$ & 26.7 & 28.4 & in jaw & 11.0 & triangular & 1 & $2 / 52 / 0$ \\
\hline FCS-10.1.1 & P4 left & Equus neogeus & $\begin{array}{l}\text { Avellaneda } \\
\text { street }\end{array}$ & 27.0 & 27.2 & in jaw & 12.4 & triangular & 1 & $1 / 42 / 0$ \\
\hline FCS-10.1.1 & M1 left & Equus neogeus & $\begin{array}{l}\text { Avellaneda } \\
\text { street }\end{array}$ & 23.4 & 27.0 & in jaw & 11.5 & triangular & 1 & $0 / 43 /$ slot \\
\hline FCS-10.1.1 & M2 left & Equus neogeus & $\begin{array}{l}\text { Avellaneda } \\
\text { street }\end{array}$ & 23.4 & 25.6 & in jaw & 11.6 & triangular & 1 & $0 / 52 / 1$ \\
\hline FCS-10.1.1 & M3 left & Equus neogeus & $\begin{array}{l}\text { Avellaneda } \\
\text { street }\end{array}$ & 29.0 & 23.2 & in jaw & 12.0 & triangular & 0 & slot $/ 43 / 1$ \\
\hline FCS-P.8 & $\begin{array}{l}\text { M1-2 } \\
\text { right }\end{array}$ & $\begin{array}{l}\text { Hippidion } \\
\text { principale }\end{array}$ & $\begin{array}{l}\text { Salto de } \\
\text { Piedra }\end{array}$ & 30.4 & 37.0 & 25.0 & 9.0 & $\begin{array}{l}\text { oval } \\
\text { round }\end{array}$ & 1 & lost \\
\hline Col.num. & $\begin{array}{l}\text { Type of } \\
\text { tooth }\end{array}$ & Species & Locality & Ls & Bs & $\mathrm{Lb}$ & $\mathrm{Bb}$ & Height & postfl. & $\begin{array}{l}\text { double- } \\
\text { knot }\end{array}$ \\
\hline FCS-P.130 & m1-2 left & $\begin{array}{l}\text { Hippidion } \\
\text { principale }\end{array}$ & $\begin{array}{l}\text { Salto de } \\
\text { Piedra V } \\
\text { level }\end{array}$ & 32.0 & 17.4 & 27.1 & 15.0 & 66.0 & 9.0 & 12.1 \\
\hline
\end{tabular}

sequence of this MCIII corresponding to a young individual The results of the discriminant analysis of 1PHIII indicate that this specimen is grouped within the remains of Hippidion devillei, with a correct previous classification of $88.0 \%$ of the cases and $78.7 \%$ by cross-validation (Fig. 8; Table 4 ).

Genus Hippidion Owen, 1869

Hippidion principale (LUND, 1846)

Fig. 10

Synonyms: See Prado \& Alberdi (2017).

Holotype: Upper right M2 from the older breccia of the Lagoa Santa cave (Brazil), figured by Lund (1846, pl.49, fig. 1). Peter W. Lund Collection (ZMK).
Type locality: Lagoa Santa, Minas Gerais State, Brazil.

Geographic distribution: South America, from several localities of the Buenos Aires and Santa Fé provinces (Argentina), Tarija (Bolivia), Artigas Department (Uruguay) and Toca dos Ossos and Lagoa Santa (Brazil).

Stratigraphic distribution: Pleistocene, Ensenadan and Lujanian SALMA.

Studied material: Right M1-2 (FCS-P.8); left m1-2 (FCS-P.130) and proximal epiphysis of left MTIII (FCS-P.8).

Description: We have a very worn tooth element that could correspond to a right M1-2 (FCS-P.8), where the figures are being lost, the styles almost lost, the fossettes reduced, the rounded protocone and the caballin fold reduced to a minimum notch, the hypocone is fully open, and the distal sinus is lost (Fig. 9.8); the m1-2 left (FCS-P.130, Fig. 10.1) from lower level V of Salto de Piedra is a tooth with morpho- 


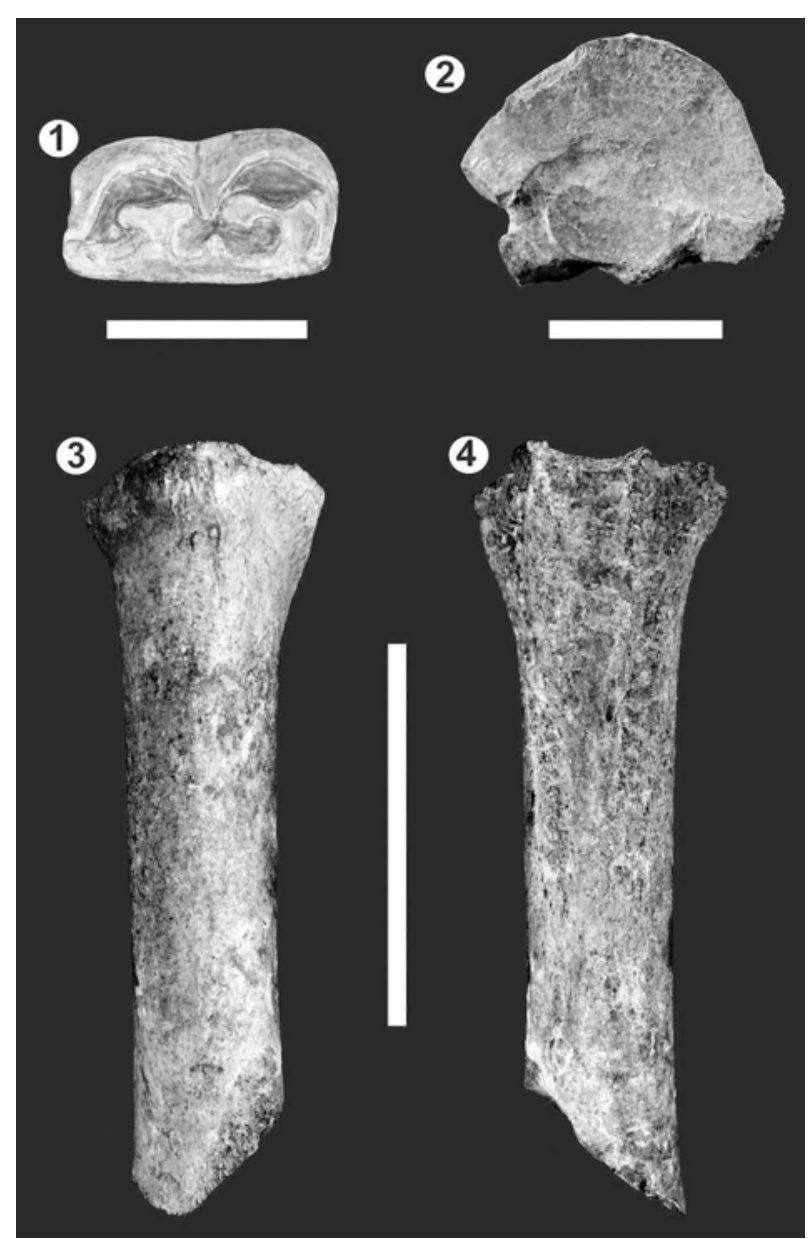

Fig. 10. Remains from the bottom level of the Salto de Piedra profile (Unit I). 1 - Lower m1-2 left in occlusal view of Hippidion principale; $\mathbf{2}$ - proximal facets of MTIII; 3 - MTIII in anterior view; 4 - MTIII in posterior view. Scales: Figs. 1 and $23 \mathrm{~cm}$; Figs. 3 and $410 \mathrm{~cm}$.

logical characteristics of Hippidion. It was little ware (measurements in Table 2), but already the figures completely formed, the metaconid-metastylid double-knot characteristic for Hippidion presents a lot of cement, the enamel in general is quite smooth and the ectoflexid crosses the isthmus without contacting the linguaflexid. No styles are detected at the base of the crown. The fragment of MTIII (FCS-P.8), also from lower level V of Salto de Piedra, is robust, typical of Hippidion principale (Fig. 10).

\section{Conclusions}

The morphological features of the dental and the appendicular skeleton of the remains from Tapalqué creek are diagnostic and permitted the identification of three species: Equus neogeus, Hippidion devillei, and Hippidion principale.

The morphological features of the skull and their dentition clearly correspond to the species Equus neogeus. This is the largest and most slender horse in South America (PRADO \& AlBERDI 2017) and appears to have predominated at middle and lower latitudes in eastern South America (Argentina, Uruguay, and Brazil). This species occupied savannas or xerophytic grasslands, and consequently would have been better adapted to open and arid landscapes. The MCIII and 1PHIII analyzed by multivariate analysis (DA of the MCIII and 1PHIII) situate these remainders with the remains previously classified as Hippidion devillei. In the case of the phalanx, we see that the percentages are smaller than in the case of MCIII, which is normal due to the fact that it is difficult to separate the anterior ones from the posterior ones in isolate phalanges and, in general, our database of phalanges is not separated in anterior and posterior ones. In most of the phalanx, horses are maintaining differences between them and we see a higher degree of overlap (Fig. 8). The rests of the carpus bones possibly correspond to Hippidion devillei as well, but this is less clear because there are very scarce remains (Table 3 ). The M1-2 right from Salto de Piedra is strongly worn, where the morphological characters of Hippidion principale are lost. In the case of left m1-2 from the lower level V at Salto de Piedra profile, this tooth exhibits morphological characteristics of Hippidion. The molar is a little worn, but already the figures are completely formed, its morphology and size suggest a large (adult) Hippidion principale. Also, the MTIII from the same level, cannot be compared in DA analysis because it is not complete; however, its measurements of the proximal epiphysis are closer to remains of Hippidion principale.

Comparative taphonomic analysis indicated that the faunal assemblages coming from the two different fossiliferous levels recognized in the Tapalqué creek stratigraphic sequence as fluvial deposits, are composed of remains affected by diverse taphonomic (processes) that are common in alluvial environments. Hippidion principale is recorded only in the lower level of the sequence (Depositional Unit I, fluvial deposits). Equus neogeus and Hippidion devillei are recorded in the middle level of the sequence (Depositional Unit II to IV, fluvial deposits). 


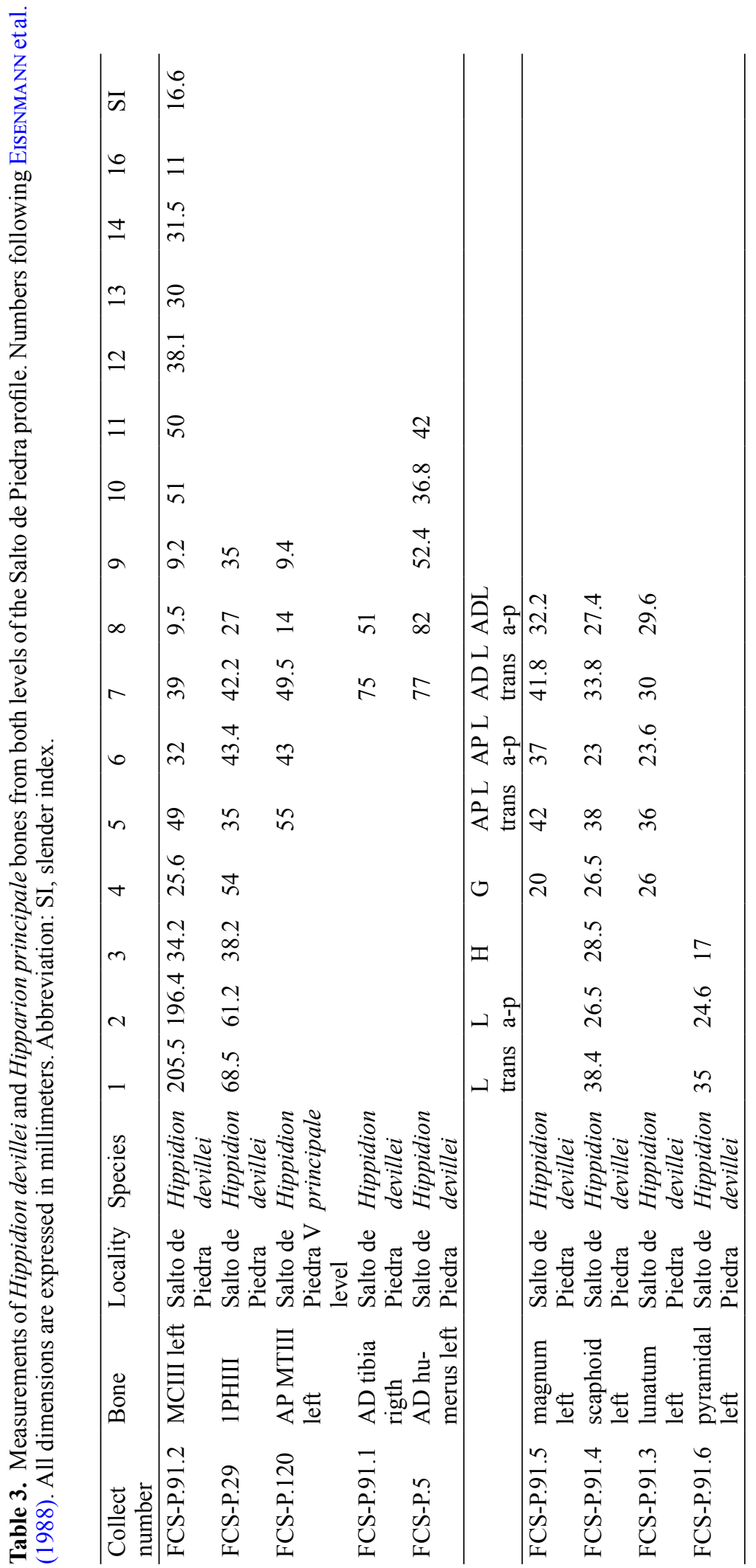


Table 4. Percentage of correct classification of Discriminant Analysis (DA) of Hippidion from the Salto de Piedra profile.

\begin{tabular}{|c|c|c|c|c|c|}
\hline & Original & Hippidion principale & Hippidion devillei & Hippidion saldiasi & Total \\
\hline \multirow{4}{*}{$\begin{array}{l}\text { McIII } \\
\text { Hippidion }\end{array}$} & H. principale & $90 \%$ & $10 \%$ & 0 & 10 \\
\hline & H. devillei & 0 & $95 \%$ & $5 \%$ & 20 \\
\hline & H. saldiasi & 0 & 0 & $100 \%$ & 5 \\
\hline & Rio Salado & $0 \%$ & 0 & $100 \%$ & 1 \\
\hline \multirow{4}{*}{$\begin{array}{l}\text { First } \\
\text { phalanx } \\
\text { Hippidion }\end{array}$} & H. principale & $100 \%$ & 0 & 0 & 32 \\
\hline & H. devillei & 0 & $91.7 \%$ & $8.3 \%$ & 12 \\
\hline & H. saldiasi & $3.2 \%$ & $22.6 \%$ & $74.2 \%$ & 31 \\
\hline & Rio Salado & $0 \%$ & $100 \%$ & 0 & 1 \\
\hline
\end{tabular}

\section{Acknowledgements}

The manuscript was greatly improved by thoughtful reviews from JoAQUIN ARroyo-CABRALES and an anonymous referee. This work has been made possible thanks to Research Project ANPCYT PICT 2015-1512 to JLP; DGICYT CGL2016-79334-P and COOP-B20287 from Spain to MTA; and Grant of the National University of Central Argentina (UNICEN) and CONICET to INCUAPA. The authors thank DAN RAFUSE for improving the language.

\section{References}

Alberdi, M.T. (1987): La Familia Equidae, Gray, 1821 (Perissodactyla, Mammalia) en el Pleistoceno de Sudamérica. - IV Congreso Latinoamericano de Paleontología, Santa Cruz de la Sierra, Bolivia, 1: 484-499.

Alberdi, M.T. \& Frassinetti, D. (2000): Presencia de Hippidon y Equus (Amerhippus) (Mammalia, Perissodactyla) y su distribución en el Pleistoceno Superior de Chile. - Estudios Geológicos, 56: 279-290. doi: 10.3989/ egeol.00565-6144

Alberdi, M.T. \& Prado, J.L. (1993): Review of the genus Hippidion Owen, 1869 (Mammalia; Perissodactyla) from the Pleistocene of South America. - Zoological Journal of the Linnean Society, 108: 1-22. doi: 10.1111/ j.1096-3642.1993.tb02559.x

Alberdi, M.T. \& Prado, J.L. (2004): Caballos fósiles de América del Sur. Una historia de tres millones de años. Universidad del Centro de la Provincia de Buenos Aires, INCUAPA serie monográfica, Olavarria, 3: 1-269.

Alberdi, M.T., Cartelle, C. \& Prado, J.L. (2003): El registro Pleistoceno de Equus (Amerhippus) e Hippidion (Mammalia, Perissodactyla) de Brasil. Consideraciones paleoecológicas y biogeográficas. - Ameghiniana, 40: 173-196.

Alberdi, M.T., Fernández, J., Menegaz, A.N. \& PraDO, J.L. (1986): Hippidion Owen 1869 (Mammalia, Perissodactyla) en sedimentos del Pleistoceno tardío de la localidad Barro Negro (Jujuy, Argentina). - Estudios Geológicos, 42: 487-493. doi: 10.3989/egeol.86426780

Alberdi, M.T., Menegaz, A.N. \& Prado, J.L. (1987): Formas terminales de Hippidion (Mammalia, Perissodactyla) de los yacimientos del Pleistoceno Tardío-Holoceno de la Patagonia (Argentina y Chile). - Estudios Geológicos, 43: 107-115. doi: 10.3989/egeol.87431-2577

Alberdi, M.T., Menegaz, A.N., Prado, J.L. \& Tonni, E.P. (1989): La fauna local de Quequén Salado-Indio Rico (Pleistoceno Tardío) de la provincia de Buenos Aires, Argentina. Aspectos paleoambientales y biostratigráficos. - Ameghiniana, 25: 225-236.

Alberdi, M.T., Prado, J.L. \& Favier-Dubois, C.M. (2006): Nuevo registro de Hippidion principale (Mammalia, Perissodactyla) del Pleistoceno de Mar del Sur, Argentina. - Revista Española de Paleontología, 21 (2): 105-113.

Alberdi, M.T., Prado, J.L. \& Miotti, L. (2001a): Hippidion saldiasi Roth, 1899 (Mammalia, Perissodactyla) at the Piedra Museo site (Patagonia): their implication for the Regional Economy and Environmental. - Journal of Archaeological Science, 28: 411-419. doi: 10.1006/jasc. 2000.0647

Alberdi, M.T., Zarate, M. \& Prado, J.L. (2001b): Presencia de Hippidion principale en los Acantilados Costeros de Mar del Plata (Argentina). - Revista Española de Paleontología, 16: 1-7.

AlcalÁ, L. (1994): Macromamíferos neógenos de la fosa de Alfambra-Teruel. Instituto de estudios Turolenses y Museo Nacional de Ciencias Naturales, Teruel. Tesis doctoral: 1-554.

Andrews, P. (1995): Time resolution of the Miocene fauna from Pasalar. - Journal of Human Evolution, 28: 343-358. doi: 10.1006/jhev.1995.1027

Ameghino, F. (1889): Contribución al conocimiento de los Mamíferos Fósiles de la República Argentina. - Actas Academia Nacional de Ciencias de Córdoba, 6: 1-1027.

Ameghino, F. (1906): Les formations sédimentaires du Crétacé supérieur et du Tertiaire de Patagonie avec un parallèle entre leurs faunes mammalogiques et celles de l'ancien continent. - Anales del Museo Nacional de Historia Natural de Buenos Aires, 8: 1-568. 
Andrews, P. (1990): Owls, Caves and fossils. - 231 pp.; London (Natural History Museum).

Bargo, M.S., Menegaz, A.N., Prado, J.L., Salemme, M.C., TAmbussi, C.P. \& TonNi, E.P. (1986): Mamíferos y biostratigrafía. Una nueva Fauna Local de la Unidad Mamífero Lujanense (Pleistoceno tardío) de la provincia de Buenos Aires. - Ameghiniana, 23 (3-4): 229-232.

Behrensmeyer, A.K. (1978): Taphonomic and ecologic information from bone weathering. - Paleobiology, 4: 150-162. doi: 10.1017/S0094837300005820

Behrensmeyer, A.K. \& Kidwell, S. (1985): Taphonomy's contributions to Paleobiology. - Paleobiology, 11: 105-119. doi: 10.1017/S009483730001143X

Behrensmeyer, A.K., Gordon, K. \& Yanagi, G. (1989). Nonhuman bone modification in Miocene fossils from Pakistan. - In: Bonnichsen, R. \& SorG, M. (eds.): Bone Modification: 9-120; Orono (Institute for Quaternary Studies, University of Maine).

BIDART, S. (1988): Estudio sedimentológico y mineralógico de los materiales parentales de los suelos no aluviales de la cuenca del río Sauce Grande, provincia de Buenos Aires. CONICET, unpublished Report.

Bonadonna, F.P., Leone, G. \& Zanchetta, G. (1995): Composición isotópica de los fósiles de gasterópodos continentales de la provincia de Buenos Aires. Indicaciones paleoclimáticas. - In: AlBerdi, M.T., Leone, G. \& TonNi, E.P. (eds.): Evolución biológica y climática de la región pampeana durante los últimos cinco millones de años. - Monografías del Museo Nacional de Madrid, 12: $1-423$.

Bonadonna, F.P., Leone, G. \& Zanchetta, G. (1999): Stable isotope analyses on the last $30 \mathrm{ka}$ molluscan fauna from Pampa grassland, Bonaerense region, Argentina. Palaeogeography, Palaeoclimatology, Palaeoecology, 153: 289-308. doi: 10.1016/S0031-0182(99)00063-2

Cantalapiedra, J.L., Prado, J.L., Hernández FernánDEZ, M. \& Alberdi, M.T. (2017): Decoupled ecomorphological evolution and diversification in NeogeneQuaternary horses. - Sciences, 355: 627-630. doi: 10.1126/science.aag1772 PMID: 28183978

Cerdeño, E., Moreiras, S. \& Alberdi, M.T. (2008): Primeros hallazgos del équido Hippidion (Perissodactyla) en el Pleistoceno de la provincia de Mendoza. - Revista Museo Argentino de Ciencias naturales, 10 (2): 211-220. doi: 10.22179/REVMACN.10.278

Cione, A.L. \& Tonni, E.P. (2005): Biostratigrafía basada en mamíferos del Cenozoico superior de la Región Pampeana. - In: Barrio, R., Etcheverry, R.O., Caballé, M.F. \& Llambías, E. (eds.): Geología y Recursos Minerales de la provincia de Buenos Aires. - Relatorio del XV Congreso geológico argentino, La Plata, 11: 183-200.

Cione, A.L., Tonni, E.P., Bargo, S., Bond, M., CandeLa, A.M., Carlini, A.A., Deschamps, C., Dozo, M.T., Esteban, G., Goin, F.J., Montalvo, I.M., Nasif, N., Noriega, I.N., Ortiz-Jaureguizar, E., Pascual, R., Prado, J.L., Reguero, M.A., Scillato-Yané, G.J., Soibelzon, L., Verzi, D.H., Vieytes, E.C., VizcaíNO, S.F. \& VuceTich, M.G. (2007): Mamíferos continentales del Mioceno tardío a la actualidad en la Argentina: cincuenta años de estudios. - Ameghiniana, Numéro Especial 50 aniversario: 257-278.
Correal Urrego, G. (1981): Evidencias Culturales y Megafauna Pleistocénica en Colombia. - Fundación Investestigación Arqueológica Nacional, 12: 1-148.

Courty, M.A., Goldberg, P. \& MacPhaIL, R. (1989): Soils and micromorphology in archaeology. - Cambridge Manuals in Archaeology (Cambridge University Press).

Cunha, F.L. (1981): Equus (Amerhippus) vandonii n.sp. um novo cavalo fossil de Corumba, Mato Grosso do Sul, Brasil. - Boletín del Museo Nacional Geología, 40: $1-19$.

Dauphin, Y. \& Brugal, J.P. (2013): Taphonomy in Archaeology. - In: UNESCO-EOLSS Joint Committee (eds.): Encyclopedia of Life Support Systems (EOLSS). Oxford (Eolss Publishers).

Denys, C., Andrews, P., Dauphin, Y., Williams, T. \& FERNÁNDEZ JALVO, Y. (1997): Towards a site classification: Comparison of stratigraphic, taphonomic and diagenetic patterns and processes. - Bulletin de la Societé Géologique de France, 168 (6): 751-757.

Denys, C., Williams, C., Dauphin, Y., Andrews, P. \& Fernández JALVo, Y. (1996): Diagenetical changes in Pleistocene small mammals bones from Olduvai Bed I. Palaeogeography, Palaeoecology.- Palaeogeography, Palaeoecology, Palaeoeclimatology, 126: 121-134. doi: 10.1016/S0031-0182(97)88905-5

Der Sarkissian, C., Vilstrup, J.T., Schubert, M., SeguinOrlando, A., Eme, D., Weinstock, J., Alberdi, M.T., Martin, F., López, P.M., Prado, J.L., Prieto, A., Douady, C.J., Stafford, T.W., Willerslev, E. \& OrLANDO, L. (2015): Mitochondrial genomes reveal the extinct Hippidion as an outgroup to all living equids. - Biology Letters, 11: 20141058. doi: 10.1098/rsbl.2014.1058 PMID: 25762573

Dodson, P. (1973): The significance of small bones in paleoecological interpretation. - Contributions in Geology, University of Wyoming, 12: 15-19.

EFremov, I. (1940): Taphonomy: a new branch of paleontology. - Pan-American Geologist, 74: 81-93.

Eisenmann, V., Alberdi, M.T., De Giuli, C. \& Staesche, U. (1988): Studying Fossil Horses: Methodology, 1: 1-72; Leiden (Brill).

FERnÁndeZ-JALVo, Y. \& ANDrews, P. (2016): Atlas of Taphonomic Identifications. - 359 pp.; Vertebrate Paleobiology and Paleoanthropology Series (Springer). doi: 10.1007/978-94-017-7432-1

Fernández-Jalvo, Y., Andrews, P., Pesquero, D., Smith, C., Marín-Monfort, D., SÁnchez, B., etal. (2010): Early bone diagenesis in temperate environments: Part I: Surface features and histology. - Palaeogeography, Palaeoclimatology, Palaeoecology, 288: 62-81. doi: 10.1016/j.palaeo.2009.12.016

Fidalgo, F., De Francesco, F. \& Colado, U. (1973): Geología superficial en las Hojas Castelli, J.M. Cobo y Monasterío (Provincia de Buenos Aires). $-5^{\circ}$ Congreso Geológico Argentino, Actas, 4: 27-39.

Fidalgo, F., De Francesco, F. \& Pascual, R. (1975): Geología superficial de la llanura bonaerense. Relatorío: Geología de la Provincia de Buenos Aires. - Sexto Congreso Geológico Argentino: 103-138.

Fidalgo, F., Riggi, J.C., Gentile, R., Correa, H. \& PorRO, N. (1991): Los "Sedimentos postpampeanos" con- 
tinentales en el ámbito sur bonaerense. - Revista de la Asociación Geológica Argentina, 46: 239-256.

Figini, A., Fidalgo, F., Huarte, R., Carbonari, J. \& GenTILE, R. (1995): Cronología radiocarbónica de los sedimentos de la Formación Luján en Arroyo Tapalqué, provincia de Buenos Aires. - Actas $4^{\mathrm{a}}$ Jornadas Geológicas y Geofísicas Bonaerenses, 1: 119-124.

Gaillard, M.C. \& Castellanos, Z.J.A. (1976): Moluscos Gasterópodos Hydrobiidae. - In: Ringuelet, R.A. (ed.): Fauna de Agua dulce de la República Argentina: 1-39; Buenos Aires (Fundación para la Educación, la Ciencia y la Cultura).

Garcia, M.E., Bonini, R., Alberdi, M.T. \& Pardo, J.L. (2018): First record of Equus neogeus from Abaucán River (Catamarca, Argentina). - Estudios Geológicos, 74 (2): e080. doi: 10.3989/egeol.43201.499

Gardenal, M. (1986): Geomorfología del partido de Saliquelló, provincia de Buenos Aires. - CIC Unpublished Report: 1-60.

Gervais, P. (1855): Recherches sur les Mammifères fossiles de l'Amérique méridionale. - 63 pp.; Paris (Bertrand).

GRAY, J.E. (1821): On the natural arrangement of vertebrate animals. - London Medical Repository Review, 15: 296-310.

GuÉRIN, C. (1991): La fauna des vertébrés du Pleistocène supérieur de l'aire archéologique de Sao Raimundo Nonato (Piaui, Brésil). - Comptes Rendus de l'Académie des Sciences, Paris, 312: 567-572.

HART, M.B. (2012): Geodiversity, palaeodiversity or biodiversity: where is the place of palaeobiology and an understanding of taphonomy? - Proceedings of the Geologists' Association, 123: 551-555. doi: 10.1016/ j.pgeola.2012.05.006

Heusser, C.J. (1989): Climate and chronology of Antarctica and adjacent South America over the past 30,000 yr. Palaeogeography, Palaeoclimatology, Palaeoecology, 76: 31-37. doi: 10.1016/0031-0182(89)90101-6

HoffstetTER, R. (1950): Algunas observaciones sobre los caballos fósiles de América del Sur. Amerhippus gen. nov. - Boletín Informativo de Ciencias Nacionales, 3 : 426-454.

Hoffstetter, R. (1952): Les Mammifères Pléistocènes de la République de l'Équateur. - Mémoires de la Societé Géologique de France, Nouvelle Série, 31: 1-391.

Hogg, A.G., Hua, Q., Blackwell, P.G., Buck, C.E., GuILDerson, T.P., Heaton, T.J., Niu, M., Palmer, J.G., ReImER, P.J., Reimer, R.W., TuRney, C.S. \& ZimmermanS.R. (2013): IntCal13 and Marine 13 Radiocarbon Age Calibration Curves 0-50,000 years cal BP. - Radiocarbon, 55 (4): 1889-1903. doi: 10.2458/azu js_rc.55.16783

IRIONDO, M. \& GARCIA, M.O. (1993): Climatic variations in the Argentine Plains during the last 18,000 years. - Palaeogeography, Palaeoclimatology, Palaeoecology, 101: 209-220. doi: 10.1016/0031-0182(93)90013-9

Isla, F., Rutter, N., Schnack, E. \& ZÁrate, M. (2000): La transgresión Belgranense en Buenos Aires. Una revisión a cien años de su definición. - Asociación Geológica Argentina, (D), Publicación especial, 4: 3-14.

KorTH, W. W. (1979): Taphonomy of micovertebrate fossil assemblages. - Annals of the Carnegie Museum, 48: 235-285.
LiNNAEUS, C. (1758): Systema naturae peregna tria naturae, secundum classes, ordines, genera, species cum characteribus, differentiis, synonymis, locis. Editio decimal, reformata. - 824 pp.; Stockholm (Laurentii Salvii).

López-GonzÁLEZ, F., GRANDAL-D’ANGLADE, A., \& RAMóN Vidal-Romaní, J. (2006): Deciphering bone depositional sequences in caves through the study of manganese coating. - Journal of Archaeological Science, 33: 707-717. doi: 10.1016/j.jas.2005.10.006

LuND, P.W. (1840): Nouvelles recherches sur la faune fossile du Brésil. - Annales des Sciences Naturelles, 13: 310-319.

LuND, P.W. (1846): Meddelelse af det Udbytte de 1844 Undersogte Knoglehuler Have Avgivet til Kundskaben om Brasiliens Dyreverden for Sidste Jordomvaeltning. - Det Kongelige Danske Videnskabernes Selskabs Naturvidenskabelige Og Mathematisk Afhandlinger, 12: 57-94.

LymAn, R.L. (1994): Vertebrate Taphonomy. - 524 pp.; Cambridge (Cambridge University Press). doi: 10.1017/ CBO9781139878302

MacFadden, B.J. (1992): Fossil Horses. Systematics, Paleobiology and Evolution of the Family Equidae. New York (Cambridge University Press).

MacFadden, B.J. (2013): Dispersal of Pleistocene Equus (Family Equidae) into South America and calibration of GABI 3 based on evidence from Tarija, Bolivia.-PlosOne, 8 (3): e59277. doi: 10.1371/journal.pone.0059277 PMID: 23527150

MacFadden, B.J., Siles, O., Zeitler, P., Johnson, N.M. \& Campbell, K.E. (1983): Magnetic Polarity Stratigraphy of the Middle Pleistocene (Ensenaden) Tarija Formation of Southern Bolivia. - Quaternary Research, 19: 172-187. doi: 10.1016/0033-5894(83)90003-0

Machado, H., Grillo, O., Scott, E. \& Avilla, L. (2017): Following the footsteps of the South American Equus: Are autopodia taxonomically informative? - Journal of Mammal Evolution, 25 (3): 397-405. doi: 10.1007/ s10914-017-9389-6

Mancini, M.V., Paeza, M.M., Prieto, A.R., Stutz, S., Tonello, M. \& Vilanova, I. (2005): Mid-Holocene climatic variability reconstruction from pollen records ( $32^{\circ}-52^{\circ} \mathrm{S}$, Argentina). - Quaternary International, 132: 47-59. doi: 10.1016/j.quaint.2004.07.013

Marshall, L. (1989): Bone modification and "The laws of burial". - In: Bonnichsen, R. \& SorG, M. (eds.): Bone Modification: 7-24; Orono (Institute for Quaternary Studies, University of Maine).

Mikulášs, R. (1999): Notes to the concept of plant trace fossils related to plant-generated sedimentary structures. Bulletins of the Czech Geological Survey, 74: 39-42.

Montalvo, C.I. (2002): Root traces in fossil bones from the Huayquerian (Late Miocene) faunal assemblage of Telén, La Pampa, Argentina. - Acta Geológica Hispánica, 37: 37-42.

Montalvo, C.I. (2004): Paleobiología de la asociación faunística de Caleufú (La Pampa, Formación Cerro Azul, Mioceno superior-Plioceno inferior) a través de análisis tafonómicos. - Unpublished Ph.D. Thesis, Facultad de Ciencias Naturales y Museo, Universidad Nacional de La Plata: $251 \mathrm{pp}$. 
MuHs, D.R. \& ZÁRATE, M. (2001): Late Quaternary eolian records of the Americas and their paleoclimatic significance. - In: MARKGRAF, V. (ed.): Interhemispheric Climate Linkages: 183-216; Academic Press. doi: 10.1016/ B978-012472670-3/50015-X

Orgeira, M.J., Walther, A.M., Tófalo, R., VÁsquez, C.A., LiPPAI, H. \& COMPAGNUCCI, R. (2001): Estratigrafía y magnetism de rocas en un perfil del arroyo Tapalqué; Cuaternario de la provincia de Buenos Aires: implicancias paleoambientales y paleoclimáticas. - Revista de la Asociación Geológica de Argentina, 56 (3): 353-366.

Orlando, L. Male, D., Alberdi, M.T., Prado, J.L., PriETO, A., CoOper, A. \& Hänni, C. (2008): Ancient DNA clarifies the Evolutionary History of American Late Pleistocene Equids. - Journal of Molecular Evolution, 66: 533-538. doi: 10.1007/s00239-008-9100-x PMID: 18398561

Owen, R. (1840): The Zoology of the voyage of H.M.S. Beagle under the Command of Captain Fitzroy R.N. during the years 1832 to 1836. Part I. Fossil Mammalia, Ed. Superv. C. Darwin: 81-111.

Owen, R. (1848): Description of teeth and portions of jaws of two extinct anthracotherioid quadrupeds (Hyopotamus vectianus and Hyop. bovinus) discovered by the Marchioness of Hastings in the Eocene deposits on the NW coast of the Isle of Wight: with an attempt to develop Cuvier's idea of the classification of pachyderms by the number of their toes. - Quarterly Journal of the Geological Society, 4: 103-141. doi: 10.1144/ GSL.JGS.1848.004.01-02.21

Owen, R. (1869): On fossil teeth of equines from Central and South America, referable to Equus conversidens, Equus tau, and Equus arcidens. - Proceeding of the Royal Society of London, 17: 26-268.

Pascual, R. \& Ortiz Jaureguizar, E. (1990): Evolving climates and Mammal faunas in Cenozoic South America. Journal of Human Evolution, 19: 23-60. doi: 10.1016/ 0047-2484(90)90011-Y

Pascual, R., Ortega Hinojosa, E.J., Gondar, D. \& TonNI, E.P. (1965): Las edades del Cenozoico mamalífero de Argentina con especial atención a aquellas del territorio bonaerense. - Anales de la Comisión de Investigación Científica, 6: 165-193.

Pascual, R., Ortega Hinojosa, E.J., Gondar, D. \& TonNI, E.P. (1966): Las edades del Cenozoico mamalífero de la provincia de Buenos Aires. - In: Borrello, A.V. (ed.): Paleontología Bonaerense. Comisión de Investigaciones Científicas de la Provincia de Buenos Aires: 3-12.

Pascual, R., Ortiz Jaureguizar, E. \& Prado, J.L. (1996): Land mammals: paradigm of Cenozoic South American geobiotic evolution. - In: Arratia, G. (ed.): Contribution of Southern South America to Vertebrate Paleontology. - Münchner Geowissenschaftliche Abhandlungen, (A), 39: 265-319.

Paula Couto, C. (1979): Paleomastozoología. - 590pp.; Río de Janeiro (Academia Brasileira de Ciencias).

PorTA, J. DE (1960): Los Équidos fósiles de la Sabana de Bogotá. - Boletín de Geología, Universidad Industrial de Santander, Colombia, 4: 51-78.
Prado, J.L. (1984): Fenética de los metatarsianos de taxa fósiles Hippidion Owen, Onohippidium Moreno, Parahipparion C. Ameghino y Equus (Amerhippus) Linne (Mammalia, Perissodactyla). - CIPFE Orione Contribuciones en Biología, Montevideo, 11: 11-15.

Prado, J.L. \& Alberdi, M.T. (1994): A quantitative review of the horse Equus from South America. - Palaeontology, 37: 459-481.

Prado, J.L. \& Alberdi, M.T. (1996): A cladistic analysis of the horses of the tribe Equini. - Palaeontology, 39: 663-680.

Prado, J.L. \& Alberdi, M.T. (1999): The mammalian record and climate change over the last 13,000 years in the Pampean Region, Argentina. - Quaternary International, 57-58: 165-174. doi: 10.1016/S1040-6182(98)00057-3

Prado, J.L. \& Alberdi, M.T. (2008): Restos de Hippidion y Equus (Amerhippus) procedentes de las Barrancas de San Lorenzo, Pleistoceno tardío (Procincia de Santa Fé, Argentina). - Revista Española de Paleontología, 23: 225-236.

Prado, J.L. \& Alberdi, M.T. (2012): Equidos y gonfoterios del Pleistoceno tardío de San Pedro, provincia de Buenos Aires, Argentina. - Estudios Geológicos, 68: 261-276. doi: 10.3989/egeol.40422.143

Prado, J.L. \& Alberdi, M.T. (2014): Global evolution of Equidae and Gomphotheriidae from South America. - Integrative Zoologica, 9: 434-443. doi: 10.1111/ 1749-4877.12064 PMID: 25236414

Prado, J.L. \& Alberdi, M.T. (2016): Fossil Horses from Argentina. - In: Agnolin, F.L., Lio, G.L., Brissón Egli, F., Chimento, N. \& Novas, F.E. (eds.): Historia Evolutiva y Paleobiogeográfica de los Vertebrados de América del Sur. - Contribuciones Científicas del Museo Argentino de Ciencias Naturales "Bernardino Rivadavia", 6: 303-309.

Prado, J.L. \& Alberdi, M.T. (2017): Fossil Horses of South America. Phylogeny, Systematics and Ecology. -150 pp.; The Latin American Studies Book Series (Springer). doi: 10.1007/978-3-319-55877-6

Prado, J.L., Alberdi, M.T. \& Di Martino, V.J. (2012): Équidos y Gomphotherios del Pleistoceno tardío de las localidades de "Cascada Paleolama" y "El Conglomerado", Sudeste de la Provincia de Buenos Aires. - Ameghiniana, 49 (4): 623-641. doi: 10.5710/AMGH.28.4.2011.559

Prado, J.L., Alberdi, M.T. \& Reguero, M.A. (1998): El Registro más antiguo de Hippidion Owen, 1869 (Mammalia, Perissodactyla) en América del Sur. - Estudios Geológicos, 54: 85-91. doi: 10.3989/egeol.98541-2207

Prado, J.L., Alberdi, M.T. \& Reguero, M.A. (2000): Comentarios sobre la Geocronología, Estratigrafía y Paleontología de Vertebrados de la Fm. Uquía en el perfil de Esquina Blanca, Jujuy. Respuesta a E.P. Tonni y A.L. Cione. - Estudios Geológicos, 56: 133-137.

Prado, J.L., Alberdi, M.T., Bonini, R. \& Crispiani, H. (2018): New records of Hippidion and Equus from Salado River (Buenos Aires, Argentina). - Neues Jahrbuch für Geologie und Paläontologie, Abhandlungen, 289 (2): 123-138. doi: 10.1127/njgpa/2018/0753

Prado, J.L., Alberdi, M.T., DE los Reyes, M., Poiré, D.G. \& Conalicchio, J.M. (2013a): New material of Equus (Amerhippus) neogeus (Mammalia, 
Perissodactyla) from the late Pleistocene of Olavarría (Argentina). - Neues Jahrbuch für Geologie und Paläontologie, Abhandlungen, 269 (2): 125-134. doi: 10.1127/ 0077-7749/2013/0340

Prado, J.L., Alberdi, M.T., Martínez, G. \& GutiérREZ, M.A. (2005): Equus (Amerhippus) neogeus Lund, 1840 (Equidae, Perissodactyla) at Paso Otero 5 site (Argentina): Its implications for the extinction of South America horse. - Neues Jahrbuch für Geologie und Paläontologie, Monatshefte, 2005: 449-468.

Prado, J.L., Bonini, R., Alberdi, M.T., Scanferla, A., Pomi, L.H. \& Fucks, E. (2013b): Nuevos registros de Hippidion (Mammalia, Perissodactyla) en el Pleistoceno tardío de la provincia de Buenos Aires, Argentina. - Estudios Geológicos, 69: 239-253. doi: 10.3989/ egeol.40991.224

Prado, J.L., Martínez-Maza, C. \& Alberdi, M.T. (2015): Megafauna extinction in South America: A new chronology for the Argentine Pampas. - Palaeogeography, Palaeoclimatology, Palaeoecology, 425: 41-49. doi: 10.1016/j.palaeo.2015.02.026

Prado, J.L., Menegaz, A.N., Tonni, E.P. \& Salemme, M.C. (1987): Los Mamíferos de la Fauna Local Paso Otero (Pleistoceno Tardío), Provincia de Buenos Aires. Aspectos Paleoambientales y Bioestratigráficos. - Ameghiniana, 24: 217-233.

Quatrrocchio, M.E. \& Borromei, A.M. (1998): Paleovegetational and paleoclimatic changes during the Late Quaternary in southwestern Buenos Aires province and southern Tierra del Fuego (Argentina). - Palynology, 22: 67-82. doi: 10.1080/01916122.1998.9989503

Quattrocchio, M.E., Borromei, A.M., Deschamps, C.M., GrILL, S.C. \& ZAVALA, C.A. (2008): Landscape evolution and climate changes in the Late Pleistocene- Holocene, southern Pampa (Argentina): evidence from palynology, mammals and sedimentology. - Quaternary International, 181: 123-138. doi: 10.1016/j.quaint.2007.02.018

Rincón, A., Alberdi. M.T. \& Prado, J.L. (2006): Nuevo registro de Equus (Amerhippus) santaeelenae (Mammalia, Perissodactyla) del pozo de asfalto de Inciarte (Pleistoceno superior), estado Zulia, Venezuela. - Ameghiniana, 43: 529-538.

Ringuelet, R.A. (1961): Rasgos fundamentales de la zoogeografía de la Argentina. - Phycis, 22: 151-170.

SCHNACK, E.J. (1987): The emerged Quaternary shorelines in Argentina. Eustatic signature and correlations: Atlantic South Ocean. - Resumenes Cuaternario de América del Sur, Reunión Final. Proyecto 201 (IGCPUNESCO), Ushuaia: 2-6.

Schnack, E., Isla, F., De Francesco, F. \& Fucks, E. (2005): Estratigrafía del Cuaternario Marino Tardío en la Provincia de BuenosAires. Relatorio. - XVI Congreso Geológico Argentino, La Plata, 10: 182.

Simpson, G.G. (1940): Review of the mammal-bearing tertiary of South America. - Proceedings of the American Philosophical Society, 83: 649-710.

Simpson, G.G. (1971): Clasificación, terminología y nomenclatura provinciales para el Cenozoico mamalífero. - Revista de la Asociación Geológica Argentina, 26: 281-297.

Stuiver, M., Reimer, P.J. \& Reimer, R.W. (2019): CALIB 7.1 [WWW program] at http://calib.org
Tomassini, R. \& Montalvo, C. (2013): Taphonomic modes on fluvial deposits of the Monte Hermoso Formation (early Pliocene), Buenos Aires province, Argentina. Palaeogeography, Palaeoclimatology, Palaeoecology, 369: 282-294. doi: 10.1016/j.palaeo.2012.10.035

TONELlo, M.S. \& PRIETO, A.R (2008): Modern vegetationpollen-climate relationship for the Pampa grasslands of Argentina. - Journal of Biogeography, 35: 926-938. doi: 10.1111/j.1365-2699.2007.01854.X

Tonello, M.S. \& Prieto, A.R (2010): Tendencias climáticas para los pastizales pampeanos durante el Pleistoceno tardío-Holoceno: estimaciones cuantitativas basadas en secuencias polínicas fósiles. - Ameghiniana 47 (4): 501-514. doi: 10.5710/AMGH.v47i4.7

Tonni, E.P., Alberdi, M.T., Prado, J.L., Bargo, M.S. \& Cione, A.L. (1992): Changes of mammal assemblages in the pampean region (Argentina) and their relation with the Plio-Pleistocene boundary. - Palaeogeography, Palaeoclimatology, Palaeoecology, 95: 179-194. doi: 10.1016/0031-0182(92)90140-Z

Tonni, E.P., Carlini, A.A., Scillato-Yané, G.J. \& FigINI, A.J. (2003): Cronología radiocarbónica y condiciones climáticas en la "Cueva del Milodón" (sur de Chile) durante el Pleistoceno tardío. - Ameghiniana, 40 (4): 609-615.

Tonni, E.P., Cione, A.L. \& Figini, A.J. (1999): Predominance of arid climates indicated by mammals in the pampas of Argentina during the late Pleistocene and Holocene. Palaeogeography, Palaeoclimatology, Palaeoecology, 147: 257-281. doi: 10.1016/S0031-0182(98)00140-0

Ubilla, M., Perea, D., Goso, C. \& Lorenzo, N. (2004): Late Pleistocene vertebrates from northern Uruguay: tools for biostratigraphic, climatic and environmental reconstruction. - Quaternary International, 114: 129-142. doi: 10.1016/S1040-6182(03)00048-X

VoorhIES, M.R. (1969): Taphonomy and population dynamics of an Early Pliocene vertebrate fauna Knox County, Nebraska. - Contributions in Geology, University of Wyoming, 1: 1-69. doi: 10.2113/gsrocky.8.special_paper_1.1

Weigelt, J. (1927): Rezente Wirbeltierleichen und ihre paläobiologische Bedeutung. Leipzig (Verlag Max Weg).

ZÁrate, M. \& Blasi, A. (1991): Late Pleistocene and Holocene loess deposits of the southeastern Buenos Aires province, Argentina. - Geojournal, 24 (2): 211-220. doi: 10.1007/BF00186018

ZÁrate, M. \& Blasi, A. (1993): Late Pleistocene-Holocene eolian deposits of the Southern Buenos Aires province, Argentina: a preliminary model. - Quaternary International, 17: 15-20. doi: 10.1016/1040-6182(93)90075-Q

ZÁrate, M. \& Flegenheimer, N. (1991): Geoarchaeology of the Cerro La China locality (Buenos Aires, Argentina): site 2 and site 3. - Geoarchaeology, 6: 273-294. doi: 10.1002/gea.3340060304

Manuscript received: August 10th, 2019.

Revised version accepted by the Stuttgart editor: November 8th, 2019. 


\section{Addresses of the authors:}

José Luis Prado, Gustavo N. Gómez, Cristian Favier Dubois, Ricardo Bonini, Pamela StefFan, INCUAPA, CONICET-UNICEN, Del Valle 5737, 7400 Olavarría, Argentina; e-mails:

jprado@soc.unicen.edu.ar; ricardo.bonin@soc.unicen.edu.ar, cfavier3@gmail.com, ggomez@soc.unicen.edu.ar, psteffan@soc.unicen.edu.ar

MARÍA Teresa Alberdi (corresponding author), Departamento de Paleobiología. Museo Nacional de Ciencias Naturales (CSIC), Madrid, España;

e-mail: malberdi@mncn.csic.es 